\title{
NA PINTURA E NOS BENS INTEGRADOS À ARQUITETURA
}

\author{
Cristina Jeannes Rozisky \\ crisroz@hotmail.com \\ Fábio Galli Alves, MALG/UFPel \\ fabiogallirestauro@uol.com.br \\ Carlos Alberto Ávila Santos, CA/UFPel \\ betosant@terra.com.br
}

\section{RESUMO}

$\mathrm{O}$ artigo conceitua o termo francês trompe l'oeil. Apresenta exemplares do ilusionismo desenvolvido em obras de cavalete e nas pinturas parietais, desde a Antiguidade ao Século XIX. Destaca as inovações técnicas e os procedimentos científicos que contribuíram para a ilusão da terceira dimensão das pinturas bidimensionais, a partir do Renascimento. Informa sobre as origens e a atuação dos arquitetos e dos pintores que edificaram os edifícios e criaram as obras arroladas. Distingue as definições de plano e profundidade. Realiza as leituras formal e iconográfica/iconológica dos exemplos apresentados. Enfoca algumas decorações murais existentes nos casarões ecléticos pelotenses, simulacros de superfícies pétreas, de lambris de madeira ou de papeis de parede.

Palavras-chave: Arquitetura; Bens integrados; Pintura; Ilusionismo.

\section{O CONCEITO DO TERMO TROMPE L'OEIL:}

A expressão francesa ${ }^{1}$ é traduzida como "engano do olho", e remete ao ilusionismo praticado por variados artistas em pinturas de diferentes épocas e culturas do mundo ocidental. Por sua vez, no dicionário eletrônico Houaiss, o termo ilusionismo é identificado como:

\footnotetext{
${ }^{1}$ Segundo o dicionário Larousse, o verbo tromper significa enganar e o substantivo oeil identifica olho.
} 
Substantivo masculino. 1. Arte de criar ilusão por meio de artifícios e truques; prestidigitação. 2. Hábito de crer em ilusões. 3. Rubrica: artes plásticas, decoração: em arte e decoração, emprego de técnicas e/ou artifícios (esp. perspectiva e sombra) com o fim de criar, no observador, uma ilusão de realidade.

Portanto, trompe l'loeil ou ilusionismo remete ao verbete simulacro. Ou seja, na simulação obtida - através de materiais e técnicas pictóricas parietais - de superfícies pétreas, de madeiras, de tecidos, etc... Em outros casos, na aparência fantasiosa de profundidade; nos efeitos ilusórios provocados pelos quadros de cavalete ou pelas obras desenvolvidas sobre os tetos e paredes dos ambientes interiores das construções religiosas ou civis, públicas, semipúblicas ou privadas: igrejas e palácios, mansões e palacetes residenciais, teatros, casas de ópera e museus, prédios comerciais e administrativos.

\section{EXEMPLARES NA HISTÓRIA DA ARTE E DA ARQUITETURA}

$\mathrm{Na}$ Antiguidade clássica, os gregos enriqueceram com ricas colorações os relevos dos tímpanos dos frontões e dos frisos - métopas e tríglifos - dos templos erguidos em homenagem às divindades. Os romanos cobriram as superfícies murais internas das residências das classes dominantes com cores fortes e contrastantes - o vermelho, o negro, o amarelo, o branco - nas quais deixavam espaços quadrangulares onde, através da técnica do afresco, representavam paisagens, naturezas mortas e narrativas pictóricas das aventuras dos deuses da mitologia. Em Pompeia, cidade que foi devastada pela erupção do Vesúvio no dia 24 de agosto do ano de 79 d.C. (CARPICECI, 2015), as escavações efetuadas a partir do século XIX revelaram que essas peculiaridades eram frequentes nas decorações dos principais cômodos das moradias.

$\mathrm{Na}$ Casa dos Vetti, cujo átrio ainda apresenta vestígios da ornamentação mural (Figura 1.1), as paredes de uma sala apresentam imitação do mármore no rodapé (Figura 1.2), segue-se uma larga faixa em vermelho enfeitada com guirlandas florais e limitada - na parte superior - por um friso de cor branca que simula cornijas em relevo. Os muros subdivididos em retângulos verticalizados - receberam pintura em um tom bastante forte do amarelo. As subdivisões são reforçadas por estreitas colunas caneladas com 
capitéis jônicos, que por meio do contraste das cores fingem destacar-se da superfície mural. Duas áreas pintadas em afresco representam arquiteturas fantásticas, que ensaiam a perspectiva. Em outra cena, ninfas circundam e coroam com louros uma figura masculina. Na última, jovens tentam derrubar um touro. As figuras e os panejamentos insinuam volumes pelo uso de claros e escuros. Mas, são representações que exploram a profundidade, o princípio de figura e fundo, segundo Wölfllin (1989).
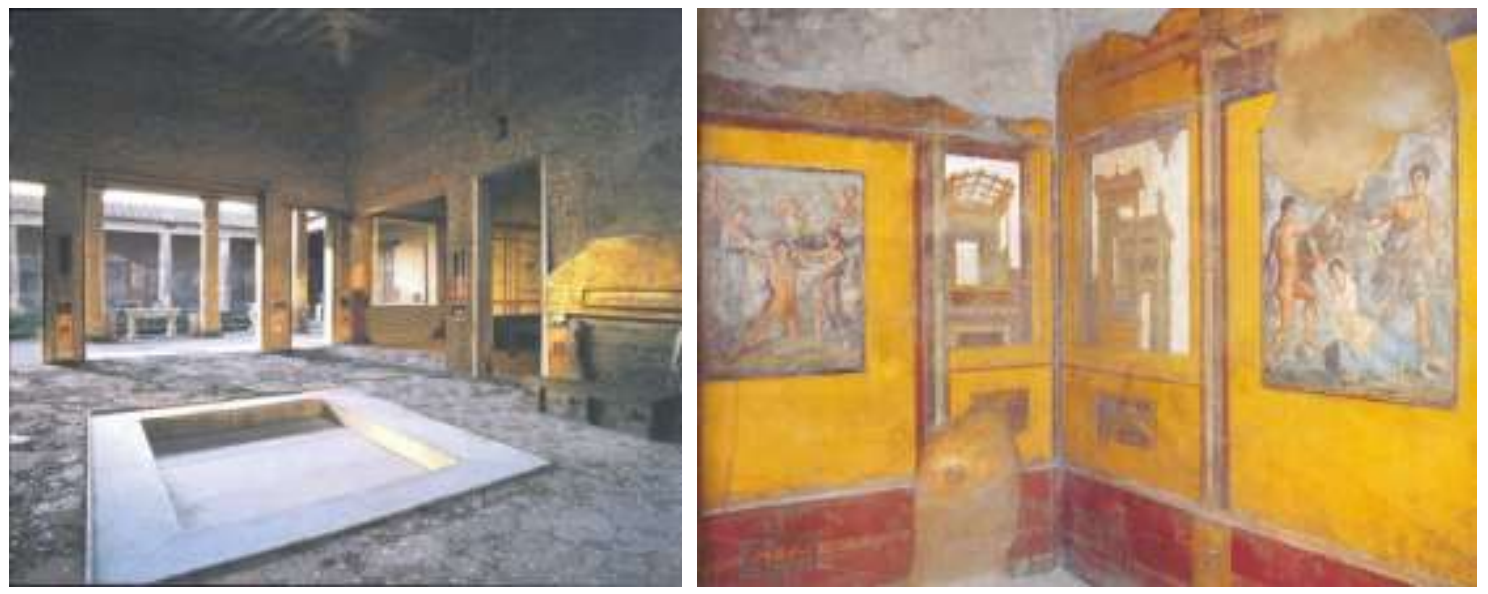

Figura 1: $\mathrm{Na}$ imagem à esquerda, 1: Átrio da Casa dos Vetti. Fonte: Pompeia reconstruída. Pompeia: Archeolibri, 2016. p. s/n. Na imagem à direita, 2: Sala da Casa dos Vetti. Fonte: CARPICECI, Alberto. Pompeia: hoje e como era 2000 anos atrás. Pompeia: Il Turismo, 2015. p. 67.

A Villa dos Mistérios (Figura 2.1) é considerada um dos monumentos mais importantes da Antiguidade, graças às pinturas parietais. No interior destaca-se uma sala decorada com os Mistérios Dionisíacos (Figura 2.2). A área central dos muros - de fundo vermelho - é subdivida em retângulos através de faixas verticais nas cores verde, ocre e negro. Sobre essa superfície estão dispostas várias figuras que, em cenas sucessivas representam a cerimônia pagã: o menino deus do vinho lê o ritual da jovem iniciada; uma sacerdotisa "oferente" leva nas mãos uma bandeja e dirige-se à "celebrante" do sacrifício sagrado, de costas para o espectador; uma "panisca" toca uma flauta e uma "satirisca" aleita um cervo; no último quadro, a iniciante parece retroceder frente às imagens de flagelação que se desenvolvem na parede seguinte (CARPICECI, 2015). Como no exemplo anterior, os volumes das figuras e os drapeados das túnicas são obtidos através dos efeitos de luz e sombra. No conjunto, a obra é bidimensional, apresenta relação de figura e fundo. 

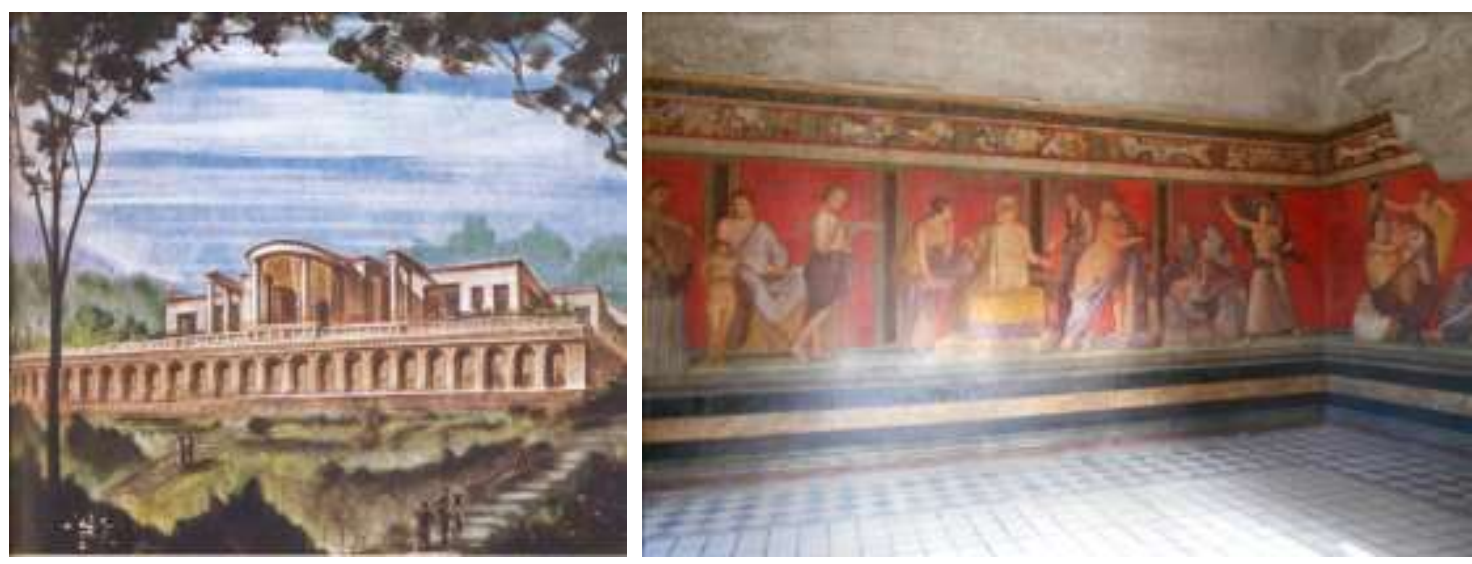

Figura 2: Na imagem à esquerda, 1: Reconstituição da fachada da Villa dos Mistérios. Fonte: CARPICECI, Alberto. Pompeia: hoje e como era 2000 anos atrás. Pompeia: Il Turismo, 2015. p. 47. Na imagem à direita, 2: Os Mistérios Dionisíacos. Fonte: Foto de Beto Santos.

Interessante salientar os diferentes frisos sobrepostos na parte inferior das superfícies murais, abaixo das encenações dos Mistérios (Figura 3.1), que alternam cores contrastantes - o vermelho, o verde e o negro - e sugerem falsas cornijas horizontais em relevo. Uma das faixas explora tons do ocre, do laranja e do amarelo (Figura 3.2), num simulacro de pedras irregulares embrechadas.
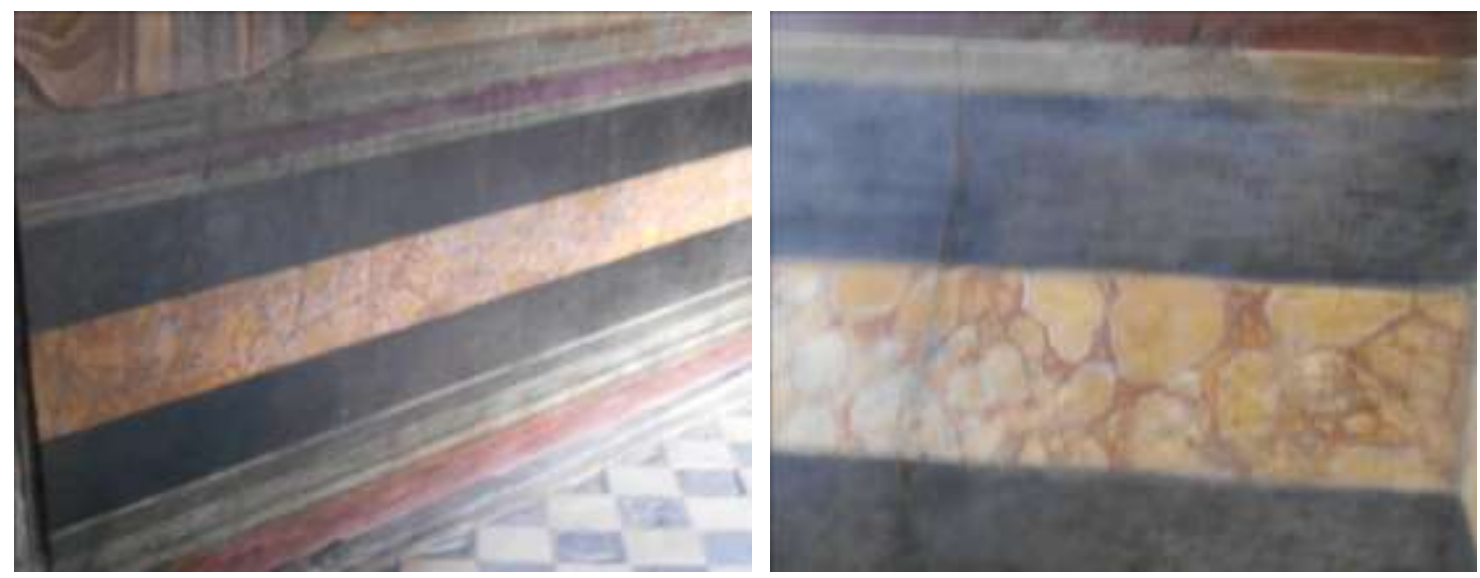

Figura 3: $\mathrm{Na}$ imagem à esquerda, 1: Frisos sob as encenações dos Mistérios Dionisíacos na Villa dos Mistérios. Na imagem à direita, 2: Detalhe da simulação das pedras irregulares embrechadas. Fonte: Fotos de Beto Santos.

Foi durante o Renascimento que as pinturas de cavalete abarcaram artifícios através do ilusório trompe l'oeil, com grande veracidade obtida através do emprego da tinta a óleo ${ }^{2}$ desenvolvida pelo pintor flamengo Jan Van Eyck (KINDERSLEY, 2013), e de métodos científicos utilizados para a representação das coisas do mundo: a perspectiva linear e a

\footnotetext{
${ }^{2}$ Até então, a pintura de cavalete era efetuada com têmpera, cuja técnica usava pigmentos diluídos em clara de ovo.
} 
aérea. Empregados pelo arquiteto florentino Filippo Brunelleschi, como fundamento dos projetos arquitetônicos, os desenhos perspectivados antagonizavam com os simbolismos e decorativismos das narrativas pictóricas realizadas até então (BECKETT, 1997). Leon Batista Alberti - outro tratadista da arquitetura nascido em Florença - foi um dos primeiros a estabelecer uma fórmula de perspectiva que pudesse ser aplicada às pinturas bidimensionais (Ibid). O método resultou em estudos minuciosos para a exploração da terceira dimensão que, na realidade, não existe nas obras. Ou seja, o procedimento implica no ilusionismo ou trompe l'oeil.
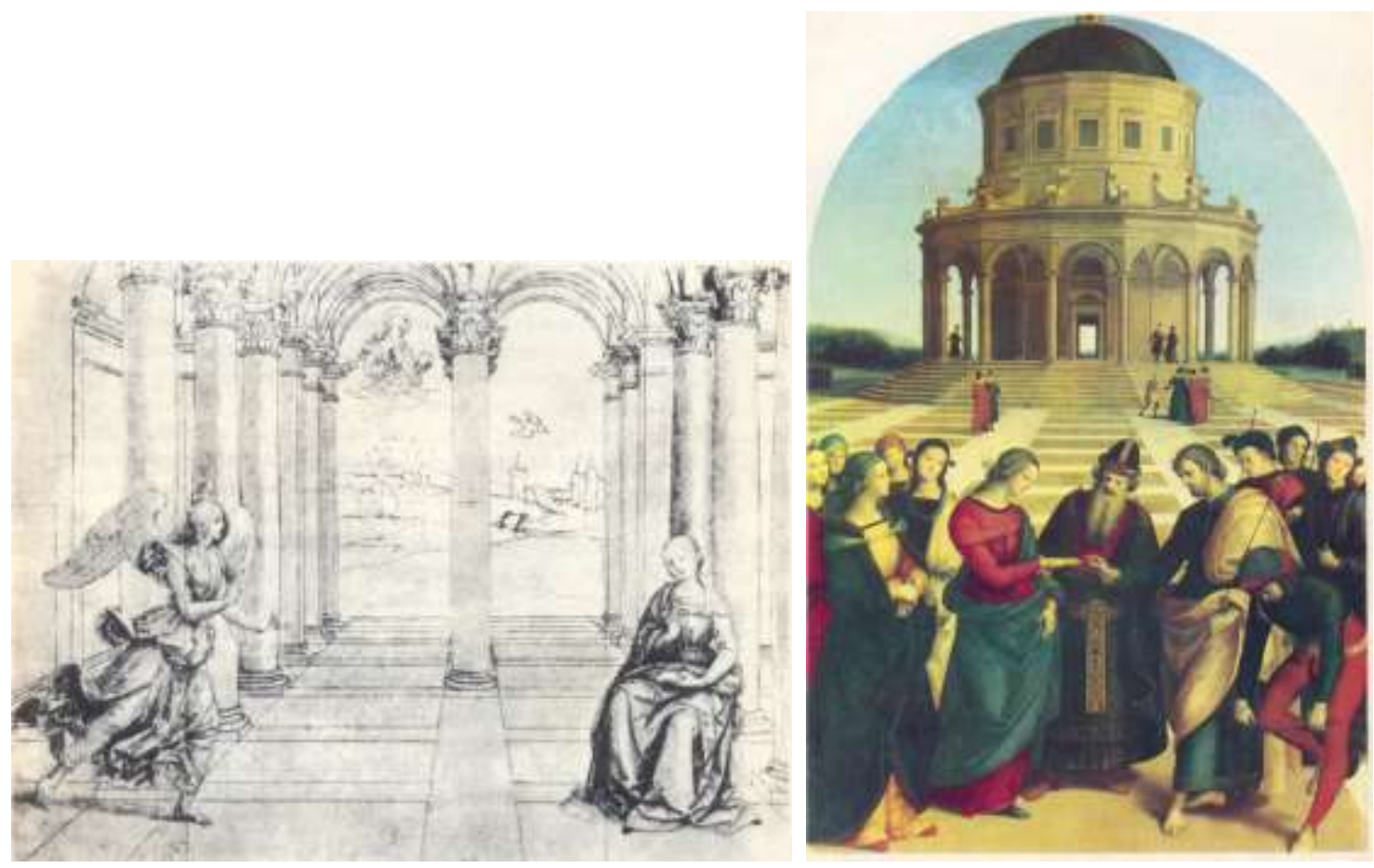

Figura 4: Na imagem à esquerda, 1: Estudo para a Anunciação. Na imagem à direita, 2: Os Esponsais da Vigem. Fonte: Fonte: Mestres da Pintura. São Paulo: Abril Cultural, 1977. pp. 17 e 36.

Ao observar a natureza com o objetivo de representá-la, o artista renascentista fechava um dos olhos. Criava-se então o ponto de fuga, para o qual foge o olhar do pintor e convergem as linhas da representação esboçada. O estudo para a Anunciação criado pelo pintor e arquiteto Rafael Sanzio da Urbino (VASARI, 2011), que hoje se encontra no Louvre, ilustra essa questão (Figura 4.1). Note-se o ponto de fuga situado um pouco ao lado do centro do desenho, marcado por uma pequena cruz. Nas lâminas de pedra que pavimentam o chão representado, as linhas traçadas dirigem-se para esse ponto. $O$ mesmo acontece com as diagonais que definem as bases dos pedestais e os capitéis das colunas que, por consequência, determinam a menor altura da colunata nos planos 
subsequentes. O esboço é minucioso e rico nos detalhes. Nos delicados personagens, o denso tracejado salienta as sombras dos corpos e das vestes, e concorre para dar volume às figuras, aos plissados das túnicas e aos drapeados do manto, que tombam em curvas sobre o chão. A obra ratifica a afirmação de muitos estudiosos: de que os artistas da Renascença eram exímios desenhistas para, depois, serem dedicados coloristas (WÖLFFLIN, 1989).

A obra Os Esponsais da Vigem (Figura 4.2), óleo sobre madeira executado por Rafael da Urbino - que data de 1504 e pertence à Pinacoteca de Brera, de Milão -, nos interessa para analisar a perspectiva aérea, que trata do colorido usado pelo pintor para enfatizar a terceira dimensão ilusória da criação desenvolvida sobre um suporte plano. No espaço representado, as linhas traçadas sobre o solo convergem para o ponto de fuga situado no vão central da porta, ao fundo. Elas respeitam a perspectiva linear e determinam os limites das lajes de pedra da pavimentação simulada, que alterna tons claros e escuros do ocre. $\mathrm{O}$ artista reuniu os principais personagens no primeiro plano. No centro, o sacerdote que realiza o matrimônio; de um lado, a Virgem Maria e um grupo de jovens mulheres; do outro, São José e um conjunto de rapazes, os pretendentes da noiva. Note-se que todos os mancebos carregam bastões e, na boca da cena, um deles quebra o adereço. O ícone simbólico e fálico remete ao sexo e à procriação que justificam o enlace cristão. Interessante salientar que Rafael vestiu as figuras elaboradas com trajes requintados, que seguem a moda da época do pintor.

No primeiro plano, como já citamos, encontram-se os indivíduos principais do tema narrado através da pintura de ideal clássico. Ao fundo, a perspectiva arquitetônica, própria da estética renascentista: as colunas com capitéis jônicos; os arcos romanos que se afirmam na colunata e suportam o teto da varanda que circunda a construção; o frontão triangular sobre a porta de entrada; o tambor e a cúpula. Depois da aglomeração figurada para o casamento, segue-se um segundo plano, vazio; outro o sucede, no qual se encontra uma dupla de homens e, do lado oposto, um grupo masculino; um quarto plano abriga a edificação e suas amplas escadas, nas laterais, novos grupos estão reunidos, a cada lado do edifício; um quinto plano é ocupado pela floresta; no sexto, as silhuetas das montanhas; no sétimo e último, o céu. Os sucessivos planos simulados permitem que o olhar do espectador vagueie no interior da representação. Há espaço para esse passeio ocular, garantido pela ilusão da falsa profundidade criada, ou na terceira dimensão irreal do quadro bidimensional. 
A perspectiva aérea contribui para esse efeito tridimensional que a obra sugere, e que é dado pelo colorido empregado. Ao observarmos o mundo real veremos que as cores dos objetos que estão mais próximos são mais intensas, e tornam-se amenas quando os mesmos se afastam do nosso campo de visão. Questão detectada pelos artistas do Renascimento. Note-se que as cores das roupas dos personagens do primeiro plano da obra de Rafael são mais vivas. Por exemplo, o vermelho usado na boca de cena é puro, por decorrência, a intensidade do pigmento foi enfraquecida com a mistura do branco pelo artista na paleta, e aplicado nos mantos de vermelho esmaecido que usam os homens agrupados no plano que antecede o templo, mais afastado. $\mathrm{O}$ mesmo ocorre no céu. Na parte mais alta, o azul é mais vibrante. Ou seja, é de um tom mais forte. Ao pintar o firmamento, de cima para baixo, na paleta o artista mesclou ao tom do azul utilizado, sucessivamente, a tinta de cor branca. E, sutilmente, foi clareando o colorido da abóboda celeste ao aproximá-la da linha do horizonte. O que provoca no olhar do espectador, ilusoriamente, a sensação de que as áreas em azul mais escuro estão mais próximas, e as seções pintadas com o azul cada vez mais claro, quase branco, por consequência estão mais longínquas.
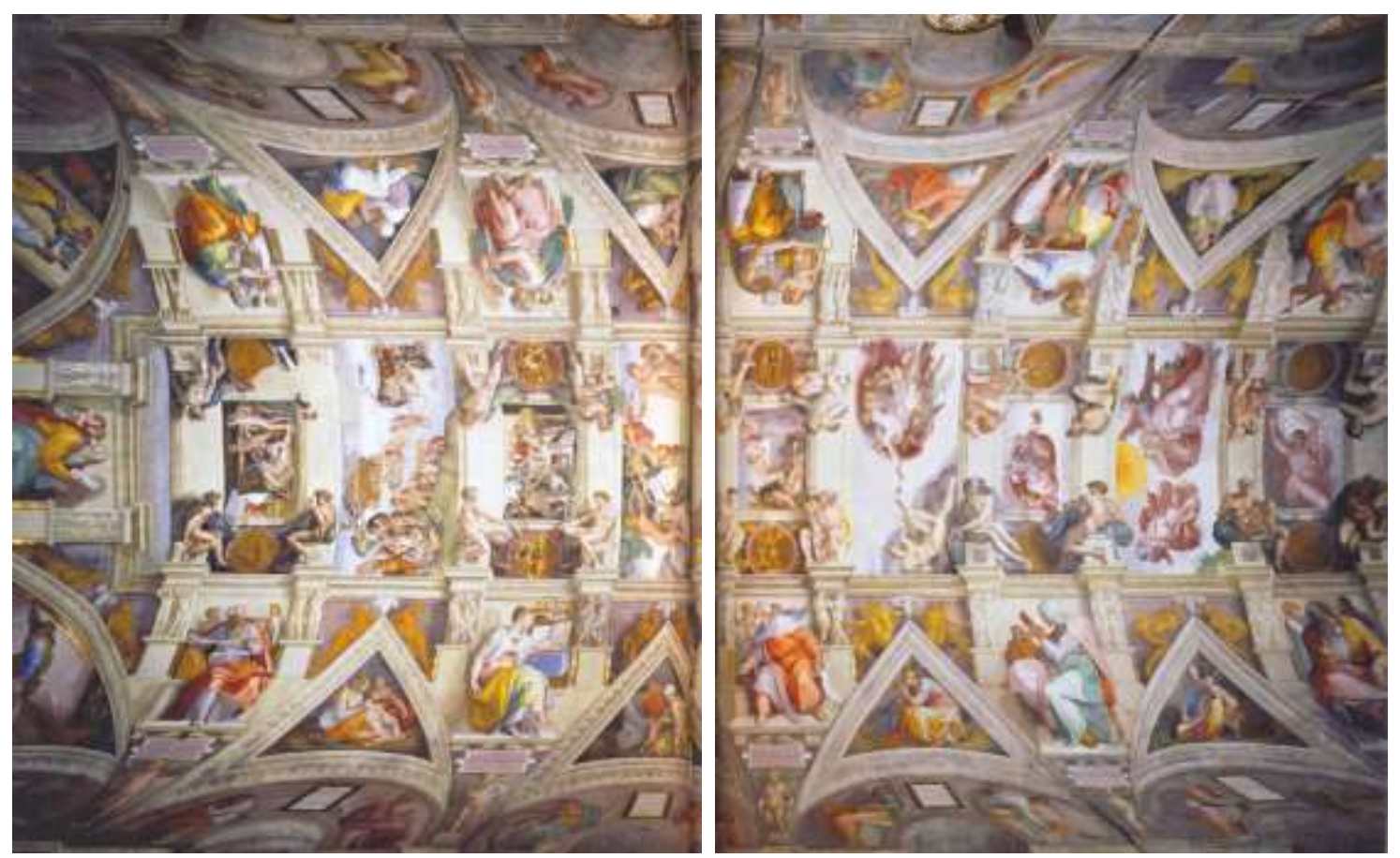

Figura 5: Nas duas imagens: Alegorias do teto da Capela Sistina. Fonte: BRUSCHINI, Enrico. Obras maetras del Vaticano. Roma: Edizioni Musei Vaticani, 2004. pp. 104 e 105. 
Entre os anos de 1508 e 1512, o escultor, arquiteto e pintor florentino Michelangelo Buonarroti desenvolveu as decorações do teto da Capela Sistina, no Palácio do Vaticano (Figura 5). Os trabalhos foram encomendados pelo Pontífice Júlio II. O nome da capela homenageia o Papa Sisto IV, que em 1477 ordenou a construção do edifício com as mesmas dimensões do Templo de Salomão - registradas na Bíblia, no Libro de los Reyes - erguido em Jerusalém no século X a.C. (BRUSCHINI, 2004). Quando da inauguração da construção no ano de 1483, o teto abobadado da Sistina se apresentava pintado em um tom de azul anil cravejado de estrelas douradas. E a parte central das superfícies murais exibia diversos afrescos, cujas temáticas abordavam a vida de Moisés e a história de Cristo. Ou seja, conjugavam o Velho e o Novo Testamento. Os diferentes afrescos foram idealizados por artistas renomados na época: Cosimo Rosseli, Domenico Ghirlandaio, Luca Signorelli da Cortona, Pietro Vannucci - conhecido como Perugino e Sandro Botticelli. Com exceção de Signorelli da Cortona e Perugino, que nasceu em Città della Pieve, todos os pintores eram naturais de Florença (VASARI, 2011).

Michelangelo subdividiu a área central da abóboda em nove seções retangulares, nas quais representou as passagens da Gênesis, identificadas como: A criação da luz; A criação do sol e da lua; A separação das terras e das águas; A criação de Adão; A criação de Eva; O pecado original; O sacrifício de Noé; O dilúvio universal; A embriaguez de Noé. Pintadas no sentido inverso da ordem cronológica dos temas. Ou seja, o pintor iniciou a obra pelo Dilúvio e a Embriaguês de Noé, e a finalizou com A criação da luz (Ibid). Note-se que as cenas e as figuras foram ampliadas durante o processo decorativo (BRUSCHINI, 2004), tornando as pranchas mais visíveis ao espectador que, do rés do chão admira a ornamentação, sobretudo, das representações intituladas: A separação das águas; A criação de Adão; O pecado original; O dilúvio. Estas são alternadas com as demais narrativas, de dimensões menores. Nas laterais do teto abobadado estampou profetas e sibilas ${ }^{3}$, que profetizaram a maternidade da Virgem Maria e o nascimento de seu filho, salvador dos pecados dos homens, segundo a doutrina cristã. Nos pendentes estucados nas laterais da abóboda e nas áreas encimadas por arcos romanos - vazadas pelas janelas - distribuiu os antepassados de Cristo e os episódios da Milagrosa Salvação de Israel.

\footnotetext{
${ }^{3}$ Profetizas pagãs da Antiguidade.
} 
Buonarroti realizou a encomenda pintando deitado sobre um andaime móvel, armado perpendicularmente à nave do templo, que poderia ser deslocado no interior do recinto e que facilitou o trabalho do artista para cobrir com os afrescos o teto e os segmentos superiores das paredes. Foi uma tarefa árdua, que ocupou quatro anos de atividade, durante os quais, pela postura obrigatória do pintor, pingos de tinta lhe caíam sobre o rosto e, sobretudo, sobre os olhos ${ }^{4}$. Verdadeiro sacrifício de fé, posto que Michelangelo trabalhou sozinho e foi auxiliado por discípulos que transpuseram os desenhos/moldes sobre papel para as superfícies murais e para o forro, também se dedicaram às misturas dos pigmentos e obtiveram os tons do colorido das tintas, sob a orientação do mestre florentino. Ordenando as diferentes cenas alegóricas bíblicas, criou em trompe l'oeil uma rede arquitetônica - com falsas cornijas, pilastras, pedestais e esculturas de grupos de putti, que emolduram os quadros da Gênesis, os profetas e as sibilas (Figura 6). Ainda, por meio do ilusionismo pictórico idealizou, em pares, vinte ignudi, ${ }^{5}$ situados nas laterais das principais alegorias; e os $\operatorname{tondos}^{6}$ monocromáticos com representações do Antigo Testamento (Figura 6).
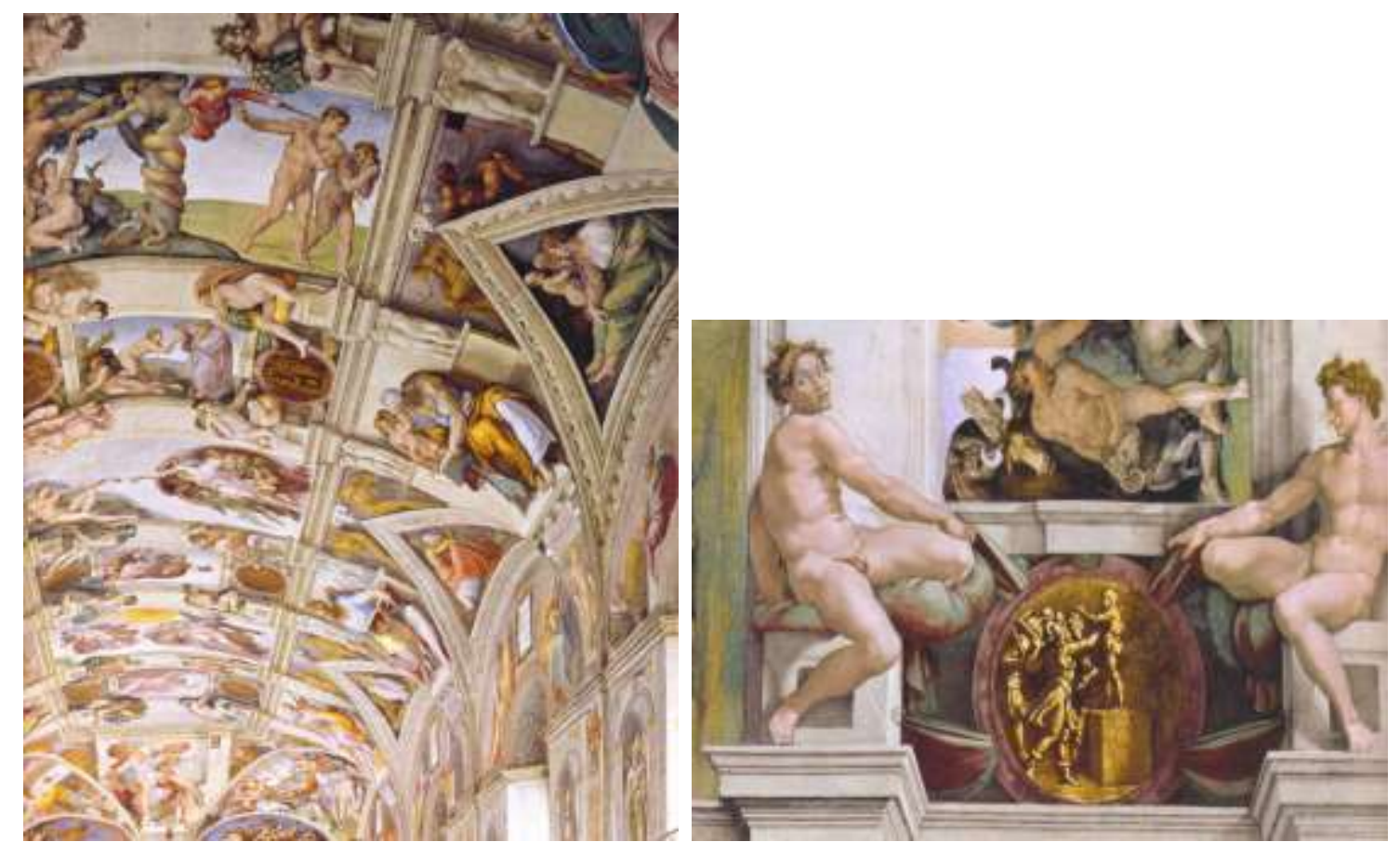

Figura 6: Nas duas imagens: Decoração e alegorias do teto da Capela Sistina. Fonte: BRUSCHINI, Enrico. Obras maetras del Vaticano. Roma: Edizioni Musei Vaticani, 2004. pp. 103 e 118.

\footnotetext{
${ }^{4} \mathrm{O}$ que prejudicava a visão do artista durante o trabalho e que poderia resultar em sequelas.

${ }^{5}$ Seres masculinos nus que cumprem a função ornamental.

${ }^{6}$ Do italiano, quadros de forma redonda.
} 
$\mathrm{Na}$ seção inferior das paredes, nos afrescos - de Rosseli, Ghirlandaio, Signorelli, Botticelli e Perugino - os artistas usaram a perspectiva linear e a aérea. As diferentes cenas são emolduradas por enfeites pintados em trompe l'loeil, simulacros de relevos em estuque pintados em branco, azul e dourado (Figura 7.1). São também falsos os panejamentos e as cortinas que estão abaixo dessas composições. As alegorias de Michelangelo adotaram a profundidade, numa antonímia de figura e fundo. Por outro lado, se as composições dos primeiros exibem simplicidade e clareza, como no detalhe da Entrega das chaves a São Pedro, de Perugino (Figura 7.1), nas quais as figuras são serenas e contidas, idealizadas segundo o classicismo renascentista, a decoração de Buonarroti é complexa, as personagens apresentam posturas e expressões faciais mais dramáticas e teatrais, os corpos curvam-se de maneira espiralada, quase impossível, como se pode ver nas imagens alegóricas dos Ignudos (Figura 5) e da Sibila Líbia (Figura 7.2). Essas peculiaridades, que subvertem as normativas artísticas do Renascimento, levaram os historiadores a classificar Michelangelo Buonarroti como um dos primeiros expoentes do estilo Maneirista (SHEARMAN, 1978).
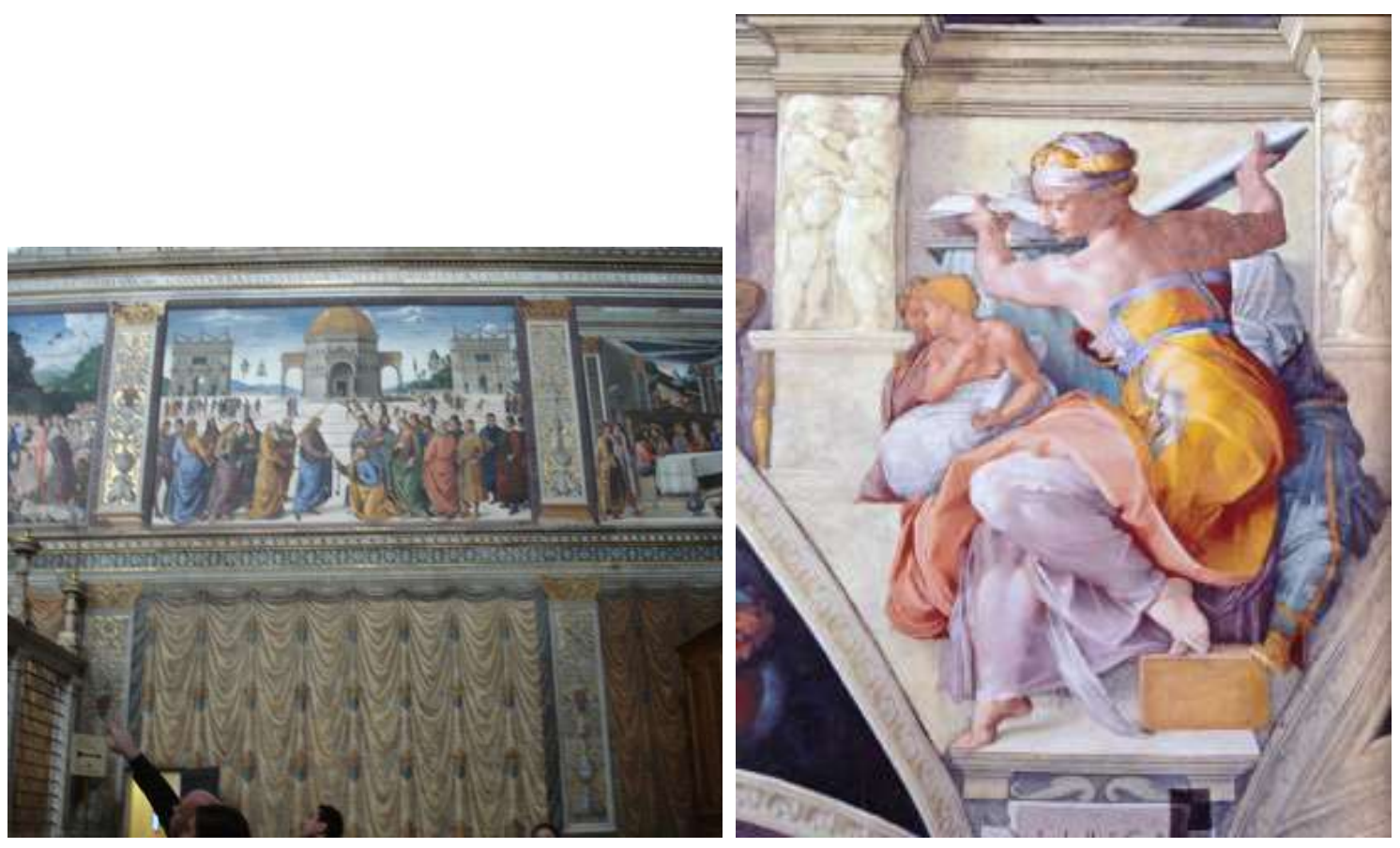

Figura 7: Na imagem à esquerda, 1: $\mathrm{O}$ afresco intitulado A Entrega das chaves a São Pedro e as decorações em trompe l'loeil. Fonte: Foto de Beto Santos. Na imagem à direita, 2: A Sibila Líbia. Fonte: BRUSCHINI, Enrico. Obras maetras del Vaticano. Roma: Edizioni Musei Vaticani, 2004. p. 126. 
Foi durante o final do século XVI e o início do XVII, que a estética maneirista evoluiu para o barroco, cujas pinturas de cavalete se estruturam em diagonais - provocando no espectador a sensação de instabilidade e movimentação. As atitudes e as expressões dos personagens são impregnadas de dramaticidade, o colorido explora fortes contrastes de cores claras e escuras, quentes e frias ou, de complementares. Os efeitos de luz e sombra alcançam aspectos tenebrosos, como exemplificam as obras de Michelangelo da Caravaggio, um dos precursores da técnica ilusionista da marouflage ${ }^{7}$ (MORA e PHILIPPOT, 2003), processo que utilizou para decorar a Capela Cantarelli com cenas alegóricas da vida de São Mateus realizadas entre 1597 e 1600 (Figura 8), no interior da Igreja de São Luís dos Franceses, em Roma (JANSON, 1972). O templo projetado por Giacomo della Porta foi construído por Domenico Fontana, entre 1518 e 1589. Porém, a edificação só teve o seu término anos depois, quando Catarina de Médici - como Regente de seu filho Charles IX no trono da França - fez doações generosas para a finalização das obras.
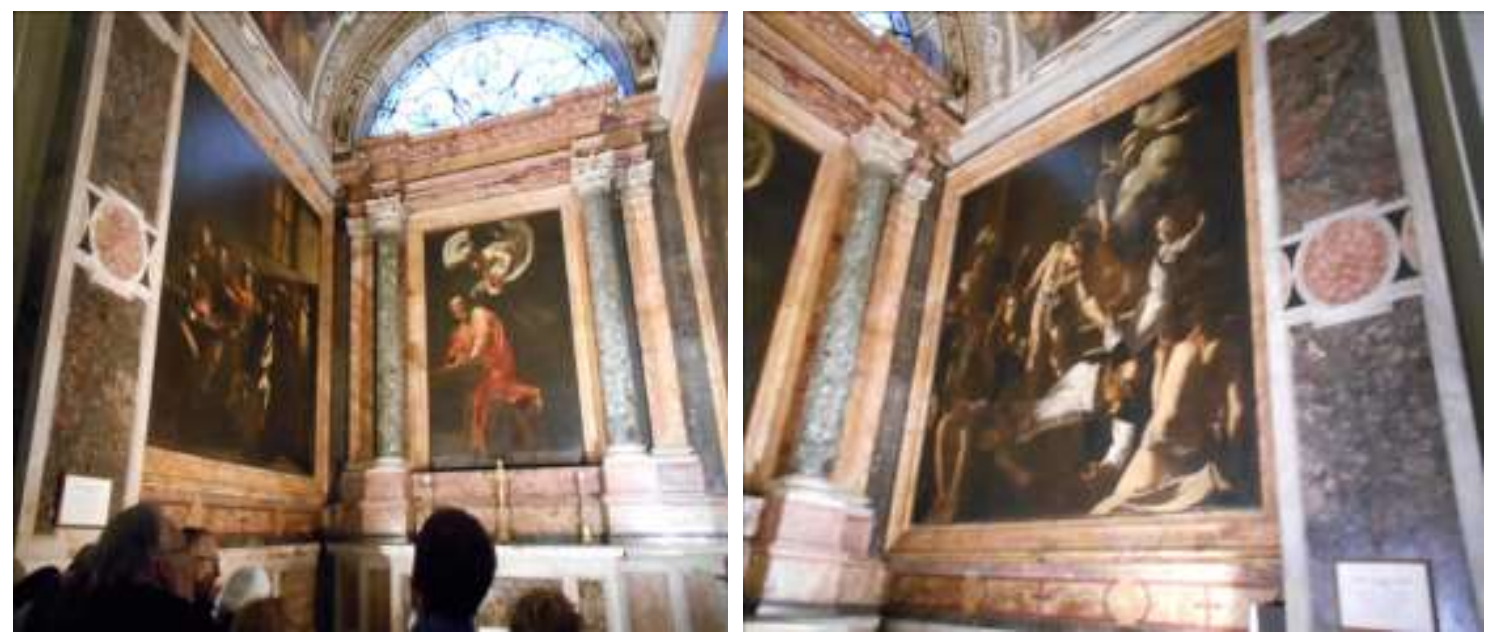

Figura 8: Nas duas imagens: As marouflages da Capela Cantarelli. Fonte: Fotos de Beto Santos.

As alegorias pictóricas desenvolvidas sobre os tetos das igrejas católicas foram comuns na arte barroca. Uma das mais espetaculares desse gênero é a decoração da Igreja de Santo Inácio de Loyola ${ }^{8}$, erguida em Roma entre os anos de 1626 e 1650, com projeto do arquiteto Orazio Grassi. A ornamentação em afresco data de 1691/94 e, é de autoria

\footnotetext{
${ }^{7} \mathrm{O}$ termo francês designa o procedimento pictórico no qual o artista pinta em separado telas que, posteriormente, são fixadas/coladas sobre a superfície a ser enfeitada.

${ }^{8}$ Nascido na Espanha, Santo Inácio foi um dos criadores da Companhia de Jesus.
} 
do irmão leigo jesuíta ${ }^{9}$ Andrea Pozzo (Figura 9). Natural da cidade de Trento, Dal Pozzo - como também é nomeado o arquiteto, decorador e pintor - foi também um tratadista do desenho perspectivado (MAINSTONE, s/d), que teorizou em dois volumes publicados em 1693 e, em 1700, com o título: Perspectiva Pictorum et Architectorum. Nessas duas obras, exemplificou os artifícios empregados na Apoteose de Santo Inácio, para obter a ilusória terceira dimensão. $\mathrm{O}$ artista fingiu, em escorço, uma perspectiva arquitetônica que projeta para a imensidão cósmica o ambiente interior da caixa mural. Os dois pórticos, a cada lado da encenação, e, em arcos plenos, são sustentados por colunas estruturadas num entablamento que intercala seções salientes e reentrantes, com falsas aberturas ladeadas por colunelos, pedestais e estuques em relevo. Estas suportam figuras masculinas e femininas e, delas alçam voo uma quantidade de santos, de anjos e de putti, em complexa movimentação. A fantasiosa edificação abre-se para uma abóboda celeste infinita, onde pairam - sobre nuvens - uma turba de novas santidades, arcanjos e querubins. À esquerda dessa espécie de medalhão celestial, o jesuíta glorificado - ascende aos céus.

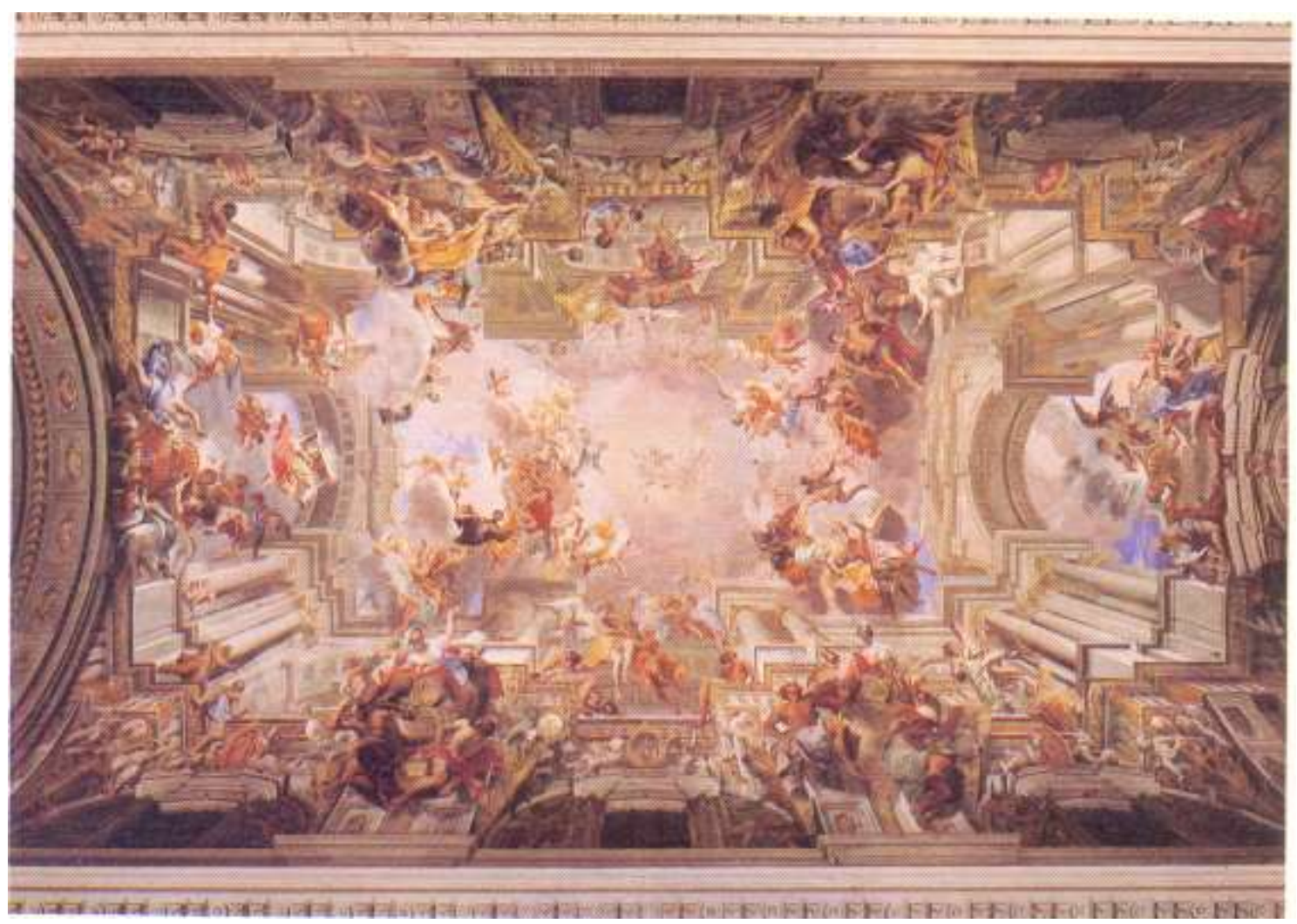

Figura 8: A Glória de Santo Inácio. Fonte: MAINSTONE, Madeleine e Rowland. O barroco e o século XVII. São Paulo: Zahar/Círculo do Livro, s/d. p. 83.

\footnotetext{
${ }^{9}$ Membros da ordem religiosa que não eram ordenados.
} 
Durante o século XVIII o estilo rococó suplantou o barroco, a estética inicialmente se desenvolveu na França de Louis XV, em seguida, se disseminou em outras cortes europeias. Mais graciosa, leve e elegante - nas composições e no colorido - a pintura rococó registrou as frivolidades e a mundanidade cotidiana da aristocracia do Velho Mundo. Em Veneza, na Ca'Rezzonico, requintado palácio projetado para a nobre família pelo arquiteto Baldassare Longhena (SANTINI, 1998) - edificado entre os anos finais do século XVII e os iniciais do XVIII, e que hoje abriga um Museu Giambattista Tiepolo decorou o teto de um salão com um ilusório afresco intitulado Alegoria do casamento dos Rezzonico com os Savorgna (Figura 10), que data de 1758 (BECKETT, 1997). Nascido na zona leste da cidade no ano de 1696, Giovanni Battista $^{10}$ executava suas obras com extrema rapidez, especializou-se na técnica do afresco e teve dois de seus nove filhos como assistentes - Domenico e Lorenzo (GRANDES ARTITAS, s/d). Em 1753, quando retornou de um estágio na Alemanha, onde enfeitou paredes e tetos do Palácio de Würzburg, Tiepolo já era consagrado e tinha realizado trabalhos em muitas villas e palacetes do Veneto, de Bérgamo e de Milão. Sua fortuna atingia cifras elevadas.

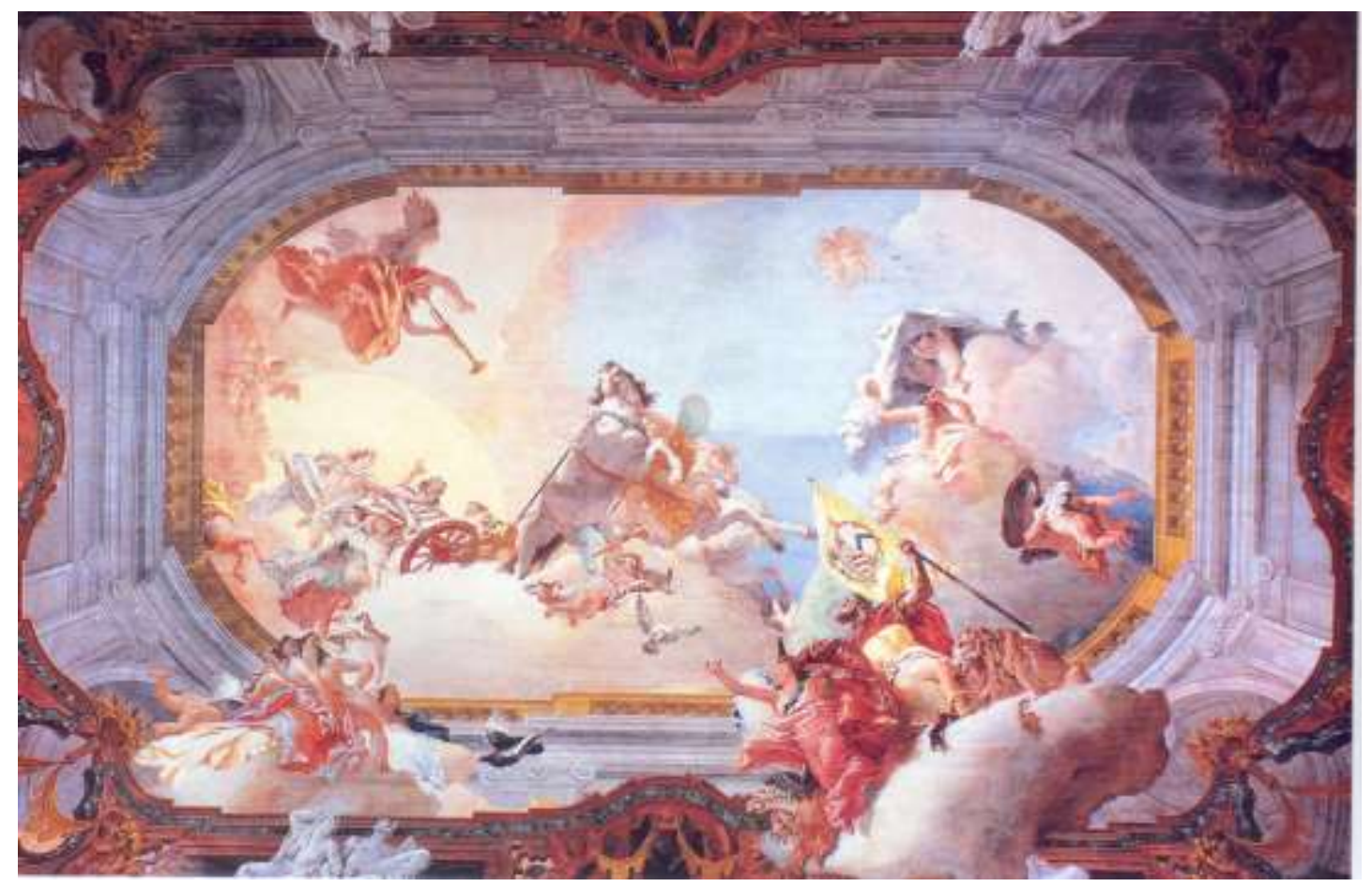

Figura 10: Alegoria do casamento dos Rezzonico com os Savorgna. Fonte: BECKETT, Wendy. História da Pintura. São Paulo: Ática, 1997. p. 232.

\footnotetext{
${ }^{10}$ Conforme bibliografia especializada em História da Arte, o nome do pintor aparece como Giambattista em algumas publicações, em outras é nomeado como Giovanni Battista.
} 
No teto plano do salão da Ca'Rezzonico, o afresco em trompe l'oeil arqueia-se de maneira esplêndida sobre a cabeça dos visitantes. A alegoria criada por Tiepolo comemora o casamento de Ludovico Rezzonico e Faustina Savorgnan, descendentes das duas famílias da nobreza veneziana (BECKETT, 1997). Nas extremidades do espaço, representou em escorço a perspectiva arquitetônica em três áreas que se complementam. $\mathrm{Na}$ primeira, o entablamento explora fingidos de mármores coloridos - onde predominam o verde, o ocre, o laranja e o branco - enfeitados com imitações de cornijas, medalhões, guirlandas e falsos conjuntos escultóricos de mármore branco. $\mathrm{Na}$ segunda seção, que se sobrepõe à primeira, as cores alternam tons de cinza azulados e simulam cornijas horizontais, pilastras com capitéis jônicos e vãos definidos por arcos romanos. A última é simulacro de uma cancela ou platibanda com balaústres, que emoldura a abóboda celeste, na qual se desenvolve a narrativa alegórica.

No centro do céu representado, por entre as nuvens surge a biga de Apolo puxada por dois cavalos pintados em escorço. O deus da beleza masculina, dos esportes e protetor da música acompanha a noiva. O casal se sobrepõe à circunferência do sol e por ela é destacado, acompanhado de vários putti esvoaçantes. A personificação da Fama anuncia o cortejo tocando uma trombeta. À esquerda do zoneamento cinza azulado, sobre uma nuvem estão recostadas as Três Graças. No lado oposto, acomodados em novas nuvens está o noivo e a figura de Afrodite, a deusa da beleza feminina e do amor. Ludovico sustém uma bandeira com os brasões familiares unidos num só emblema heráldico. Um leão - símbolo de Veneza - está deitado ao lado do noivo retratado. Acima desse grupo, a Vênus - como divindade responsável pela fertilidade - mira uma superfície espelhada sustentada por um pequeno ser alado, na qual está refletida a imagem do predestinado filho dos nubentes. Outro espelho - que remete ao futuro - é carregado por um grupo de putti, no qual ainda não se reflete a imagem do herdeiro dos clãs dos Savorgnan e dos Rezzonico. Diferentemente do ilusionismo barroco de Dal Pozzo, o trompe l'oeil rococó de Tiepolo é menos complexo e agitado e é mais lírico, singelo e sensual. Nas áreas luminosas e nas zonas sombrias empregou cores pasteis.

No Brasil, em 1764 Antônio Francisco Lisboa, o Aleijadinho, elaborou o risco da Igreja de São Francisco de Assis, em Ouro Preto, exemplar representativo do barroco resultante do ciclo do ouro de Minas Gerais (LEMOS, 1979). A data de nascimento do artista ainda não foi determinada, na certidão de nascimento consta o dia 29 de agosto de 1730, o documento de óbito do construtor e pintor acusa que ele nasceu em 1738 
(BAZIN, 1963). Era filho bastardo de uma escrava africana com o arquiteto português Manoel Francisco Lisboa, que mais tarde reconheceu o menino como filho natural. Na maturidade, Aleijadinho passou a sofrer do mal de Hansen, ou lepra, e também contraiu a porfiria, distúrbio hereditário que causa diferentes anormalidades: sensibilidade à luz do sol e a pigmentação manchada da pele; dores nos ossos e confusão mental. Ficou cego de um olho, perdeu todos os dentes e, a dor intolerável nos dedos das mãos fez com que o artista os amputasse usando um formão. Com isso, para talhar as pedras e madeiras, os instrumentos necessários eram amarrados às suas mãos por um auxiliar (MANGUEL, 2001). No interior da Igreja de São Francisco de Ouro Preto esculpiu todas as estátuas e os dois púlpitos da capela-mor.

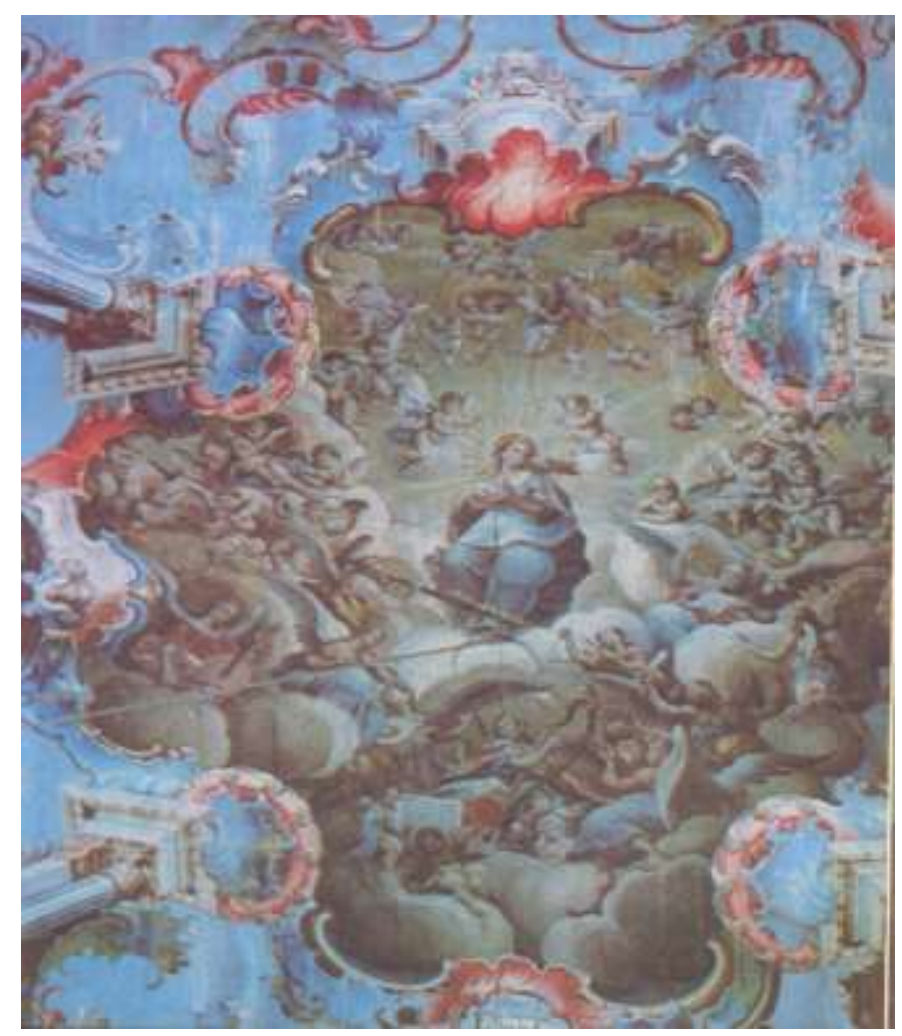

Figura 11: A Glorificação da Virgem. Fonte: BARDI, Pietro Maria. História da arte brasileira. São Paulo: Melhoramentos, 1977. p. 105.

O forro de madeira em forma de gamela, que cobre a nave, foi pintado na técnica ilusionista, como nos exemplares apresentados de Pozzo e Tiepolo (Figura 11). A obra executada entre 1801/12 representa a Glorificação da Virgem - foi criada por outro artista mineiro e mulato: o alferes e pintor Manuel da Costa Ataíde (BARDI, 1977). Além de inúmeros quadros de cavalete de sua autoria, Mestre Ataíde foi parceiro do 
Aleijadinho em várias obras. Encarnou ${ }^{11}$ as imagens da Via Sacra esculpidas em madeira por Antônio Francisco Lisboa, expostas nas capelas do Santuário do Bom Jesus de Matozinhos, em Congonhas do Campo. Manuel da Costa Ataíde nasceu em Mariana aos 18 de outubro de 1762, a diferença de idade não impediu a parceria do soldado pintor e do neurastênico escultor (LEMOS, 1979). Na Assunção idealizada (Figura 11), Ataíde criou uma perspectiva arquitetônica em escorço, com colunas e arcos plenos que se elevam para o infinito céu azul, este é vazado por um medalhão celeste com tons que vão do ocre ao dourado, onde estão dispostos - arcanjos, anjos, putti e querubins, que portam partituras e tocam instrumentos musicais. No centro da tumultuada composição, o triunfo de Maria. Interessante salientar que todos os personagens são mulatos, inclusive a Virgem. Os fortes contrastes entre as cores quentes e frias são próprios do barroco, enquanto as rocalhas, que emolduram o núcleo central, são peculiares ao rococó.

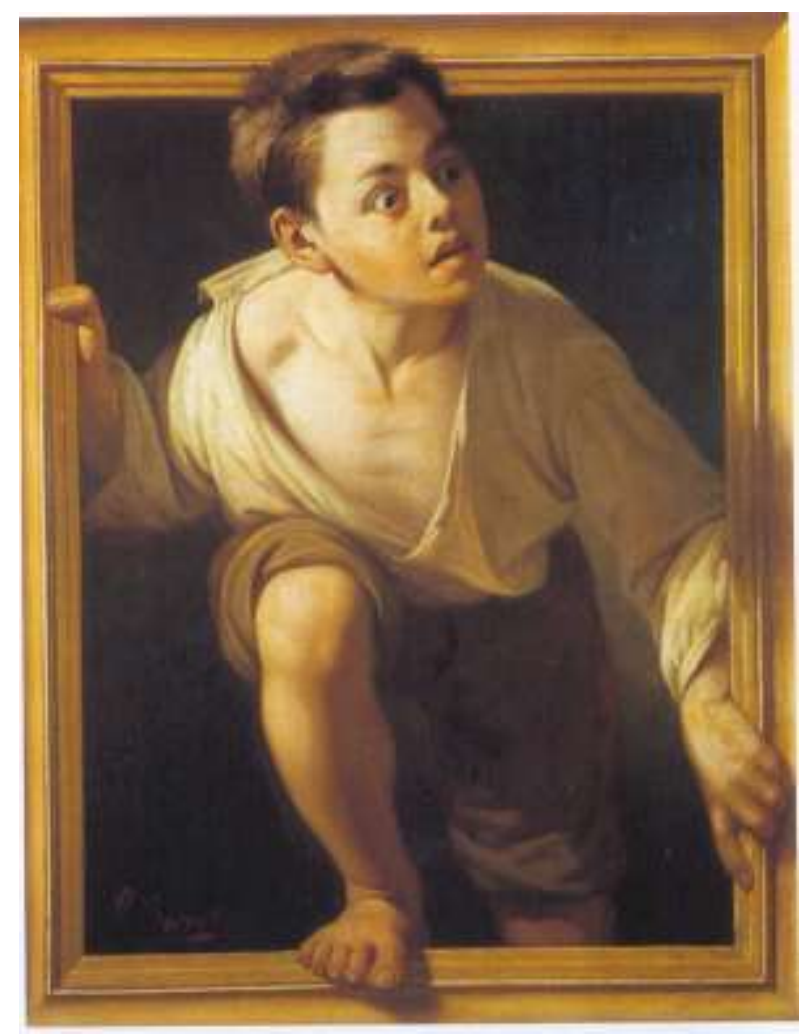

Figura 12: Em fuga da crítica. Fonte: BRADBURNE, James. Illusioni: le meraviglie del trompe l'oeil. Florença: Fondazione Palazzo Strozzi, 2009. p. 38.

\footnotetext{
${ }^{11} \mathrm{O}$ termo refere às pinturas - da pele, das carnes e do sangue expostos nas chagas, e das roupagens - das imagens sacras que representam a flagelação de Cristo e o martírio dos Santos na estética barroca.
} 
No ano de 1874 o artista espanhol Pere Borrel del Caso pintou o quadro intitulado Em fuga da crítica (Figura 12), que hoje pertence à coleção do Banco de Espanha (Figura 14). Nascido na localidade de Puigcerdà, em 1835, Pere Borrel faleceu em Barcelona em 1910 (BRADBURNE, 2009). A obra ilusionista de fundo negro é circundada por uma área pintada em trompe l'oeil, que finge - através do uso de luzes e sombras - os relevos salientes e reentrantes que emolduram a cena idealizada. Note-se que, na realidade, a pintura não apresenta moldura. A figura do menino foi flagrada no momento em que busca escapar da cena representada, sua perna avança em escorço na direção do observador, o pé se apóia na parte inferior do simulacro do caixilho de madeira dourada que arremata a composição. Como o pé, a cabeça e os dedos das mãos se sobrepõem às falsas cornijas da guarnição. Com fantástico realismo - nos panejamentos, nos membros e na pele, nos cabelos e na expressão facial - o ilusionismo foi obtido por meio dos claros e escuros decorrentes do facho de luz que - em diagonal descendente, da esquerda para a direita, em relação ao olhar do contemplador - sugere ser externo à narrativa pictórica e ter origem no mesmo espaço ocupado pelo espectador.
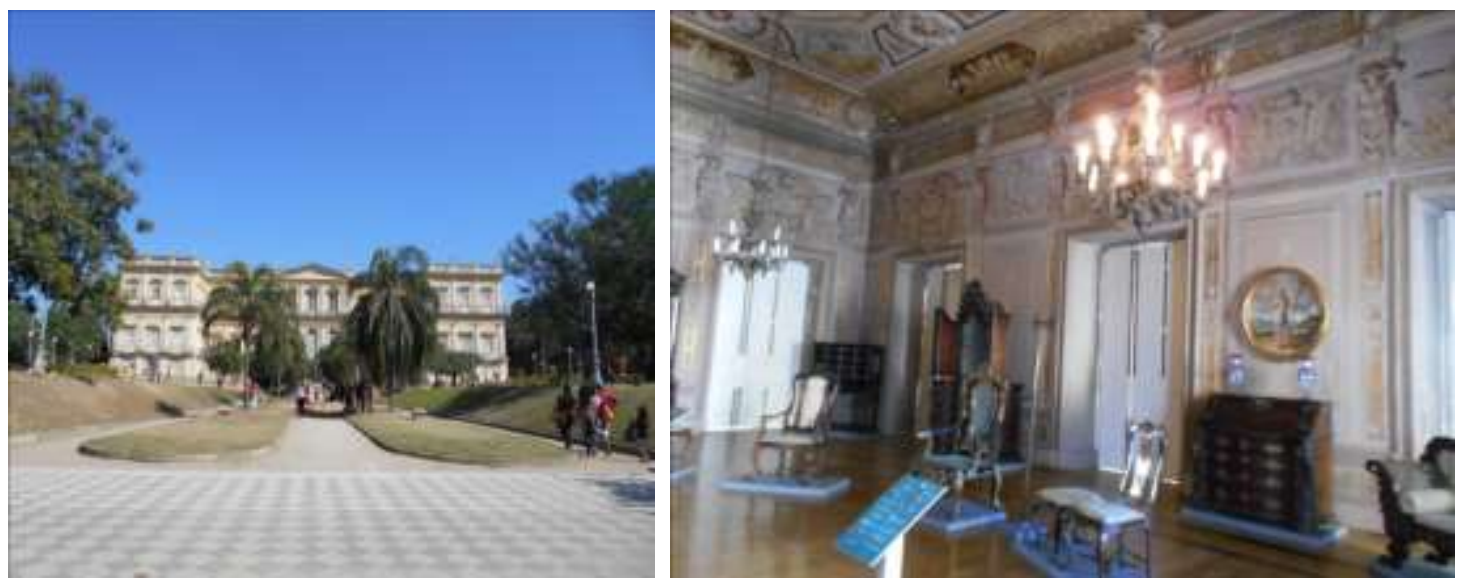

Figura 13: Na imagem à esquerda, 1: A fachada do Palácio da Boa Vista. Na imagem à direita, 2: A Sala do Trono. Fonte: Fotos de Beto Santos.

Quando do desembarque da corte portuguesa no Rio de Janeiro, em 1808, o comerciante Elias Antônio Lopes doou ao príncipe regente D. João VI uma chácara no então distante bairro de São Cristóvão, na qual edificara um palacete considerado, na época, a melhor e mais ampla construção da cidade (SCHWARCZ, 1998). D. João VI aceitou com prazer o presente. O local passou a ser denominado Real Quinta da Boa Vista, cuja localização privilegiada permitia avistar o mar, a floresta da Tijuca e o morro do Corcovado (Figura 13.1). O monarca contratou o arquiteto inglês John Johnston para 
instalar dois majestosos portões de acesso à chácara, que foram fundidos em ferro na Inglaterra. Foi também responsabilizado pela ampliação do edifício, com quatro torreões em cada canto do prédio. Muros de arrimo - arrematados por platibandas com balaústres, pilares decorados com relevos de estuque encimados por múltiplos jarros foram erguidos e delimitaram uma área ajardinada no entorno da edificação, a qual se tem acesso por meio de escadaria organizada em patamares. Foi no Palácio da Boa Vista que habitou D. Pedro I e nasceu e morou D. Pedro II, residência oficial da família real, que sofreu sucessivas alterações até o final do Império.
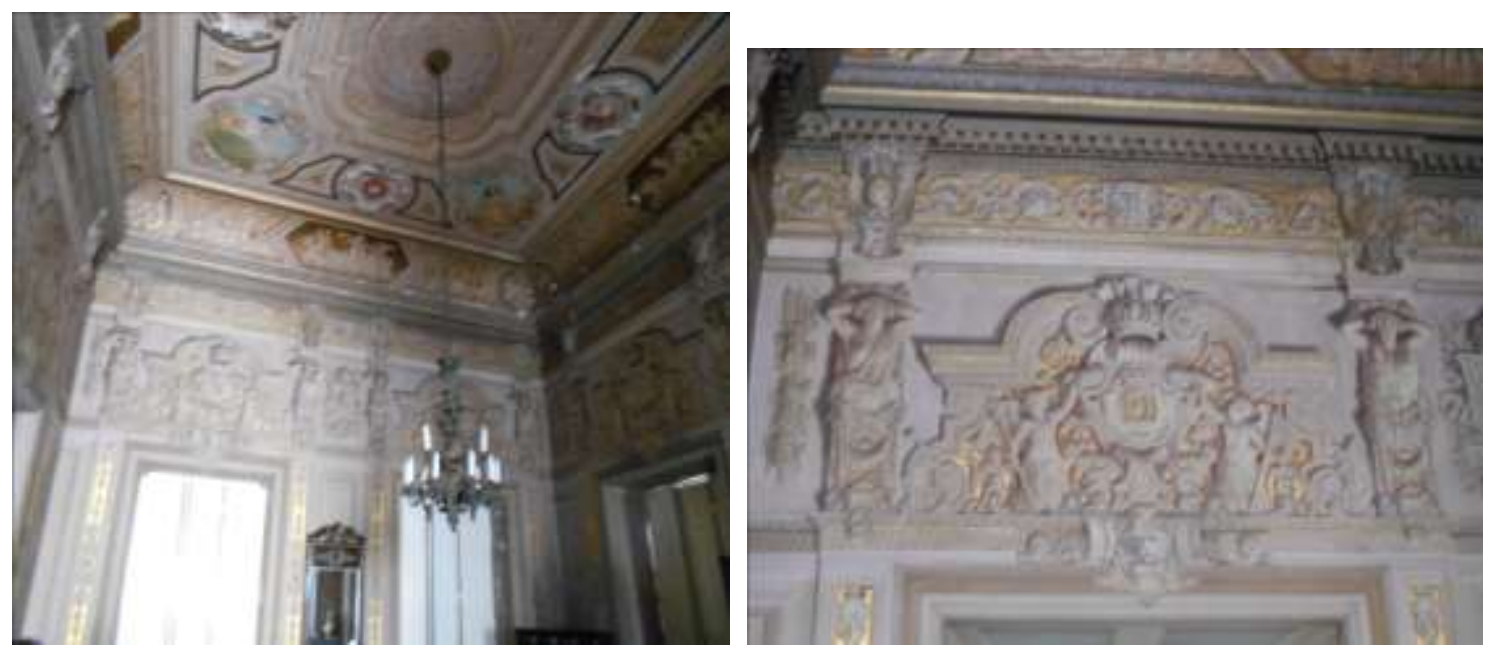

Figura 14: Na imagem à esquerda, 1: Aspecto da decoração da Sala do Trono. Fonte: Foto de Cris Rozisky. Na imagem à direita, 2: A Sala do Trono. Fonte: Foto de Beto Santos.

Atualmente, o palácio de gosto neoclássico abriga o Museu Nacional de História Natural. Muitos dos ambientes interiores foram adaptados à nova função do edifício e foram destituídos da ornamentação original. Mas, outros cômodos conservam as decorações da época, como a Sala do Trono (Figuras 13.2 e 14). As superfícies murais dessa peça receberam enfeites estucados em relevo, mesclados às pinturas ilusionistas em trompe l'oeil, que fingem ornatos salientes às paredes com grande veracidade técnica (Figura 14). São frontões cimbrados que se abrem no alto e são finalizados por volutas - onde despontam coroas - que circundam os brasões da família imperial, carregados por duas figuras aladas. Nas laterais, duas cariátides sustentam pedestais que suportam as cornijas e as guirlandas compostas por acantos, que cobrem as cimalhas. $\mathrm{O}$ fundo recebeu pintura dourada, os falsos relevos foram pintados com tintas que imitam as variantes dos tons do gesso. O uso de luzes e de sombras reforça as saliências ilusórias dos elementos decorativos. A aplicação de adereços verdadeiros, moldados em 
massa estucada, amplia o método enganoso com o qual o artista anônimo concretizou a obra.

Também no Rio de Janeiro foi erguido o palacete eclético do Barão de Nova Friburgo (Figura 15.1). O proprietário de fazendas de café Antonio Clemente Pinto recebeu o título em 1854, pelos serviços prestados ao Império brasileiro. Dentre os quais se destacou a construção da Estrada de Ferro de Cantagalo, que fomentou o transporte da produção cafeeira da região norte fluminense e destinada para a exportação (CHAGAS, 1998). O edifício residencial de Clemente Pinto foi projetado pelo alemão Gustav Waehneldt e se inspirou nos palácios venezianos, cujas obras foram encerradas por volta de 1866. O sobrado com três pavimentos tem as paredes do andar térreo cinzeladas em granito, e as dos níveis superiores em alvenaria de tijolos ornamentadas com rusticações, balcões e nichos onde se inserem estátuas alegóricas que remetem ao classicismo greco-romano. Hoje, a antiga residência abriga o Museu da República.
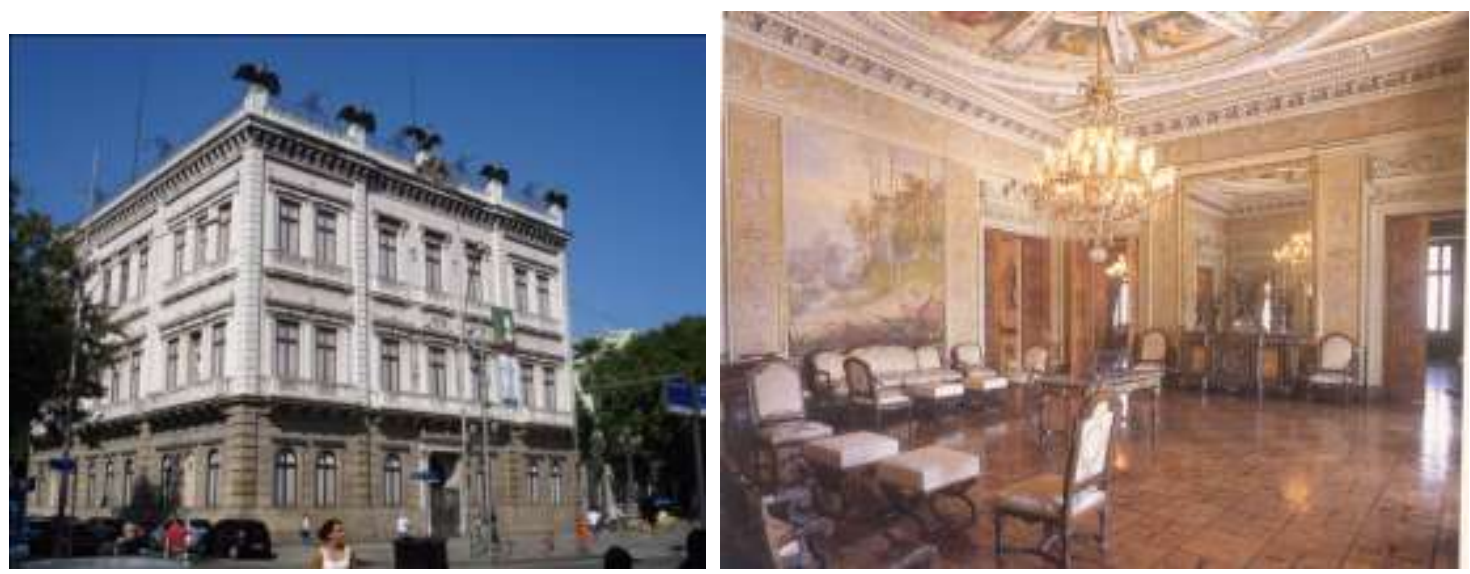

Figura 15: Na imagem à esquerda, 1: A fachada do palacete eclético do Barão de Nova Friburgo. Fonte: Foto de Beto Santos. Na imagem à direita, 2: O Salão Amarelo. Fonte: CHAGAS, Mário de Souza. Conhecendo o Museu da República. Rio de Janeiro: Ao Livro Técnico, 1998. p. 30.

Dentre as requintadas ornamentações pictóricas efetuadas nos forros e nas paredes dos ambientes interiores da edificação destacamos o Salão Amarelo (Figura 15.2). Frisos em trompe l'oeil se desenvolvem nas cimalhas dos muros e nas laterais das portas desse recinto, eles apresentam uma sucessão de putti mesclados a guirlandas florais, acantos, frutas e diferentes figuras de pequenos animais (Figura 16). Pintados sobre um fundo dourado em tons diferentes do branco - num simulacro de elementos estucados em relevo - as imagens iludem ao espectador serem salientes às superfícies murais, graças ao emprego minucioso dos claros e escuros. Como no Palácio da Boa Vista, elementos 
de estuque trabalhados em relevo - no alto das portas - colaboram para a ilusão da terceira dimensão dos fingimentos desenvolvidos nos frisos.
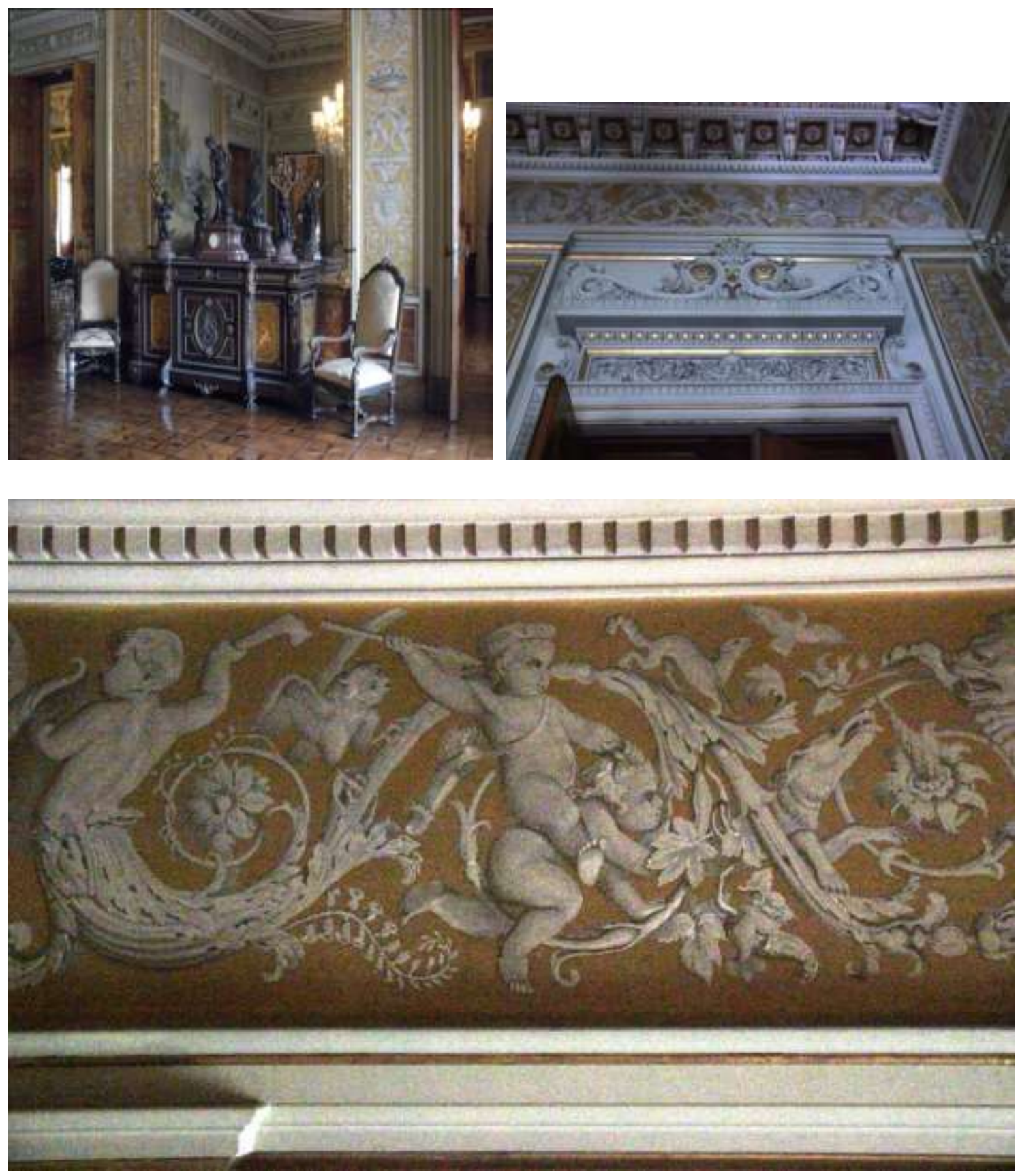

Figura 16: Nas três imagens: Diferentes aspectos dos frisos em trompe l'oeil do Salão Amarelo. Fonte: Fotos de Beto Santos e de Cris Rozisky.

Construído em lote de esquina de quarteirão voltado para a praça central da cidade, o prédio da Intendência Municipal de Pelotas foi erguido entre os anos de 1879 e 1881 (SANTOS, 2007). A caixa mural projetada pelo construtor Romualdo de Abreu e Silva seguiu a estética eclética inspirada no classicismo italiano: o porão alto; a fachada principal tripartida e enriquecida pelo pórtico de entrada estruturado por colunas com 
capitéis toscanos; a escadaria com degraus de mármore e os corrimãos com balaústres de cimento; os frontões triangulares que encimam as aberturas; as pilastras jônicas e coríntias que fragmentam e dão ritmo à composição; a platibanda cega e vazada preenchida com balaústres, que dialogam com aqueles empregados nos corrimãos de acesso (Figura 17.1). As obras foram coordenadas pelo italiano Carlos Zanotta. Os irmãos Davi e Carlos Zanotta cruzaram o Atlântico e aportaram em Montevidéu no ano de 1870, de onde continuaram viajem para Pelotas. Logo em seguida juntou-se aos dois primeiros o irmão caçula Luis. Contratados pela administração do município, os Zanotta trabalharam em obras de engenharia e de arquitetura executadas na localidade (SANTOS, 2014).
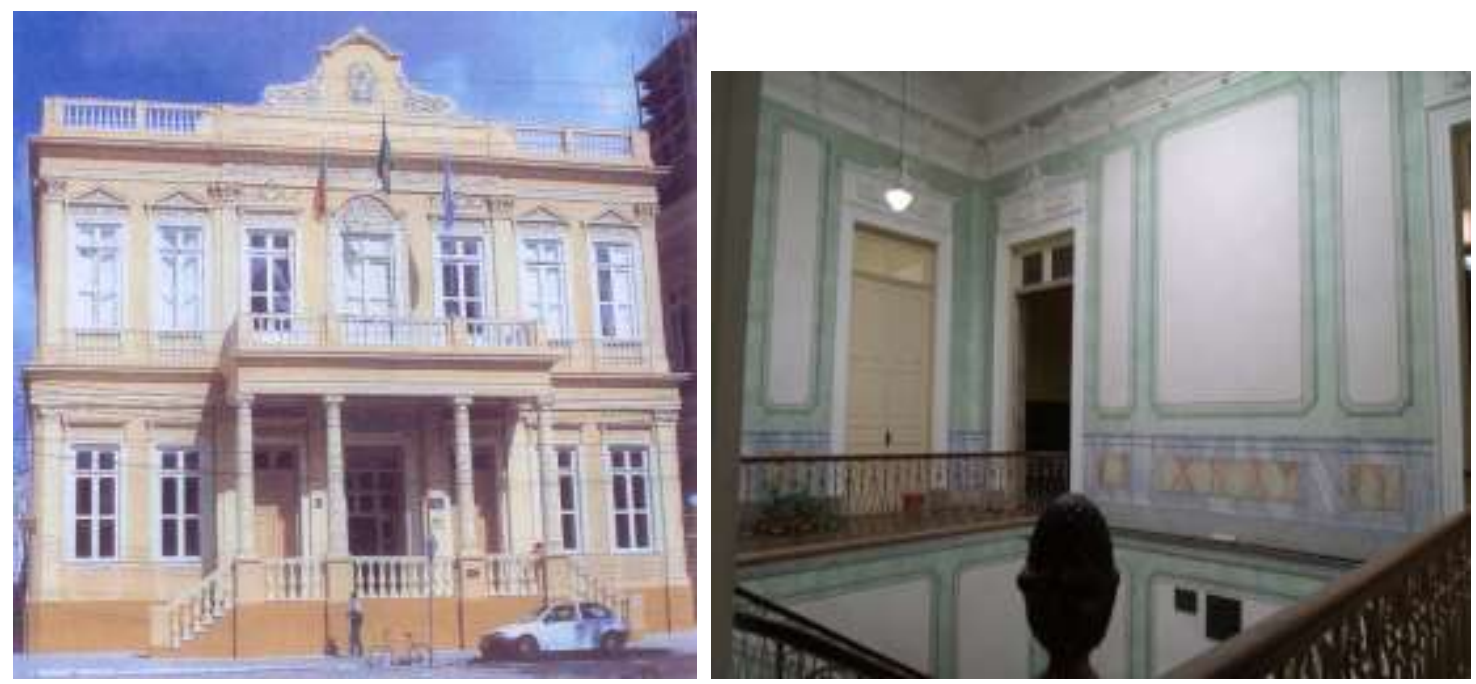

Figura 17: Na imagem à esquerda, 1: A fachada da Prefeitura. Na imagem à direita, 2: O hall da escadaria. Fonte: Fotos de Beto Santos.

No interior do edifício da Prefeitura, após o pára-vento de madeira e vidro, o pavimento térreo - divido por arcos romanos em três naves - era originalmente ocupado pelas diferentes secretarias administrativas, que atualmente estão instaladas em outros prédios do espaço urbano. Ao fundo, outro arco dá acesso à escada que leva ao segundo andar, onde estão situados os gabinetes do intendente e dos seus secretários imediatos, e o salão nobre destinado às reuniões e ao recebimento de autoridades. $\mathrm{O}$ teto do hall que abriga a escadaria recebeu lanterna em ferro e vidros coloridos, que ilumina e enfeita o ambiente. As superfícies murais são decoradas com elementos de estuque em relevo e receberam revestimento na técnica da escaiola, que fingem mármores coloridos, nos tons do branco, do azul, do verde, do laranja e do vermelho (Figura 17.2 e 18). Além do trompe l'oeil desenvolvido nos simulacros pétreos, os fingidos simulam áreas salientes 
e reentrantes e enganam o olhar do espectador: nos falsos pedestais distribuídos nas áreas inferiores das paredes; nas cornijas enganosas que seccionam os muros e emolduram os diferentes retângulos verticalizados que compõem a ornamentação.
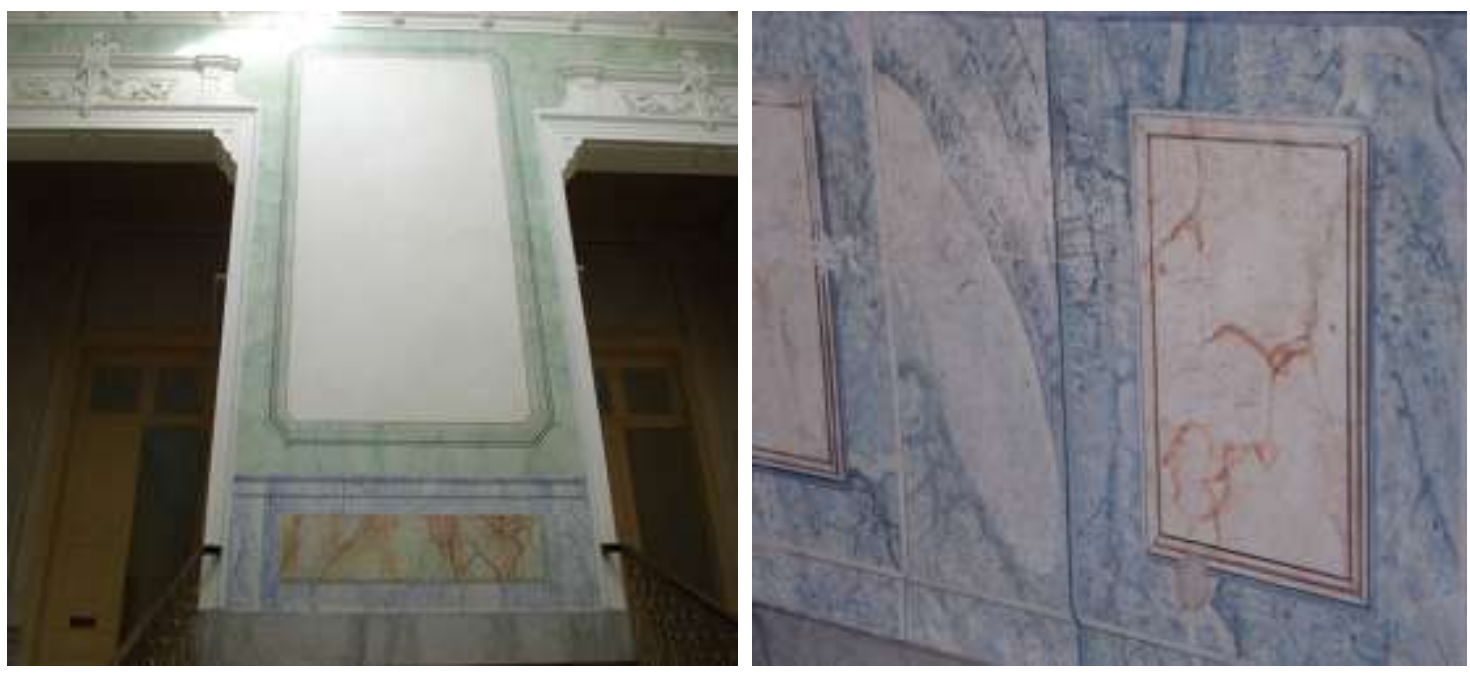

Figura 18: Nas duas imagens: Aspectos dos fingidos de mármore que enfeitam as paredes do hall da escadaria. Fonte: Fotos de Beto Santos.

Também em Pelotas, o casarão que serviu como residência do Senador Joaquim Augusto de Assumpção foi edificado em terreno de esquina da Praça Coronel Pedro Osório, entre os anos de 1884 e 1889 (SANTOS, 2007). Nas pesquisas realizadas não foi identificado o autor do projeto. Mas, as investigações apontaram que o prédio sofreu diferentes reformas ao longo do tempo: na criação do hall e do suntuoso pórtico voltados para a Rua Felix da Cunha - que substituíram o jardim originalmente existente nesse espaço; na instalação das canalizações de esgoto, em 1915; na implantação dos equipamentos para a calefação dos ambientes interiores, em 1928.

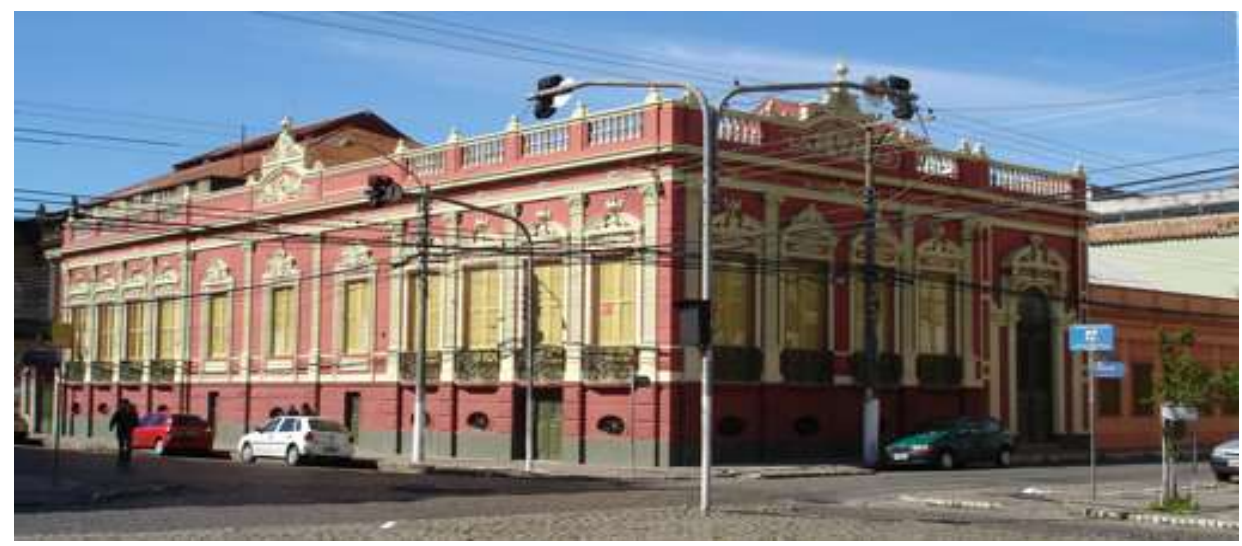

Figura 19: A fachada da antiga residência do Senador Joaquim Augusto de Assumpção Fonte: Foto de Beto Santos. 
No interior da antiga moradia, na sala de música e no salão de jantar (Figura 20) as superfícies murais receberam pinturas que fingiam lambris de madeira - na parte inferior dos muros - e papeis ornamentais - nas áreas superiores das paredes. No forro de madeira da sala destinada às refeições, os fingimentos simulavam veios na diagonal das tábuas empregadas, que criavam formas de losangos no entorno do enfeite esculpido que sustentava o lustre de iluminação do ambiente. A construção atualmente é de propriedade da Universidade Federal de Pelotas e, em reforma realizada recentemente no prédio - destinado para uma unidade administrativa da faculdade - esses elementos decorativos foram eliminados. Com isso, perderam-se os testemunhos dos procedimentos técnicos e das decorações desenvolvidas por meio do trompe l'oeil, que materializavam o "bom gosto do habitar" peculiar à elite pelotense do final do século XIX e início do XX, que restam somente nos registros fotográficos realizados durante as investigações efetuadas.
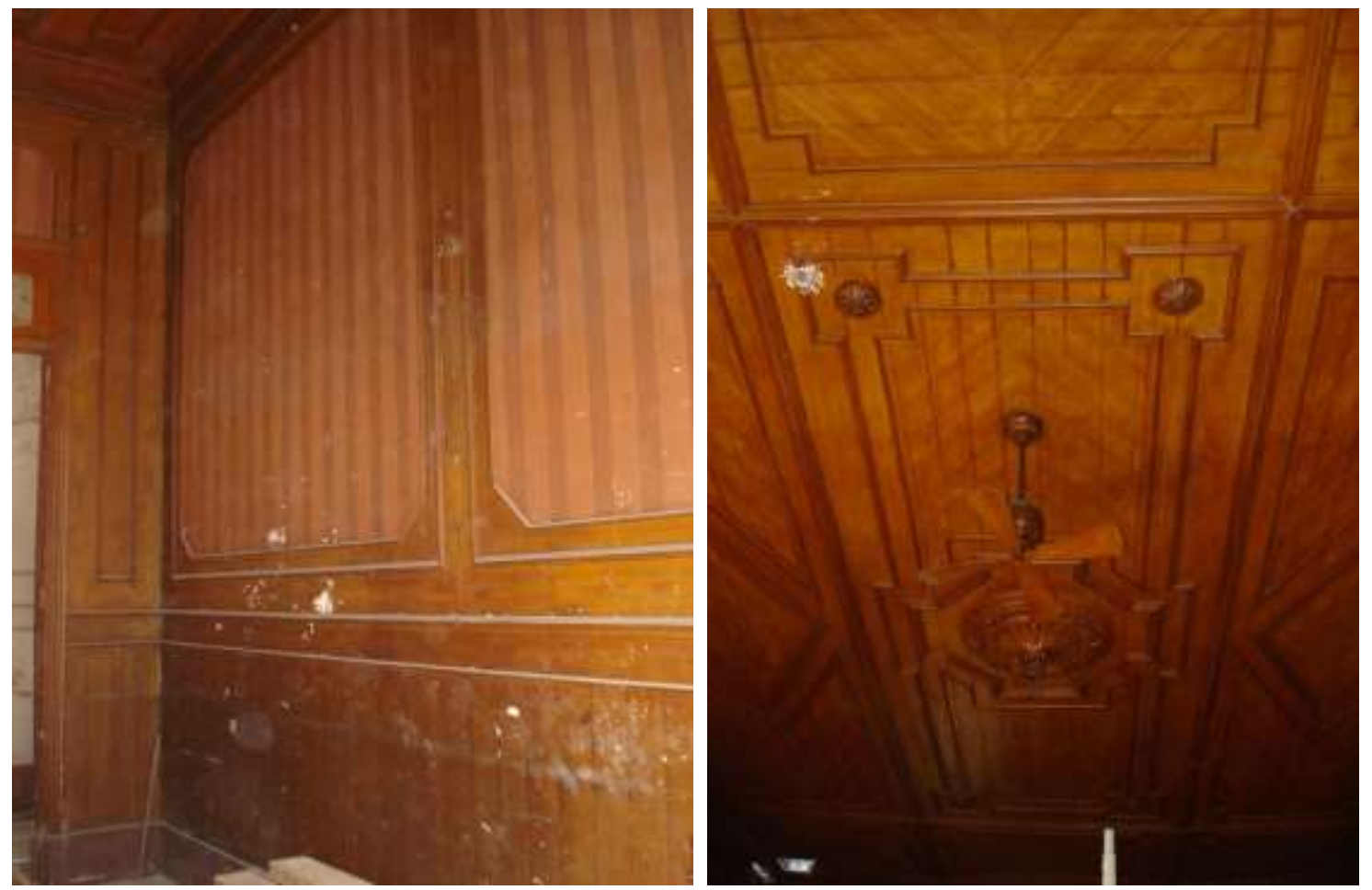

Figura 19: Na imagem à esquerda, 1: Detalhe dos fingidos da sala de música. Na imagem à direita, 2: Detalhe do tromp l'oeil no teto da sala de jantar. Fonte: Fotos de Beto Santos. 


\section{CONCLUSÃO}

Desde o classicismo da Antiguidade ao ecletismo do século XIX, variados artistas e artífices exploraram materiais e técnicas para simular a terceira dimensão em superfícies bidimensionais, praticando o ilusionismo ou trompe l'oeil em pinturas parietais ou de cavalete. A utilização de claros e escuros sugeriu volumes na iconografia empregada. Durante o Renascimento, inovações científicas e tecnológicas favoreceram esse procedimento, como: a utilização da perspectiva linear e aérea e o emprego da pintura a óleo sobre tela.

Nas decorações dos tetos e paredes da arquitetura edificada - em afresco, em marouflage ou em estuque liso e lustrado/escaiolas - desenvolveram cenas alegóricas de passagens da Bíblia e representações de Santos, conceberam alegorias mitológicas e idealizaram os deuses pagãos da cultura greco-romana, criaram simulacros de áreas salientes ou reentrantes dos planos representados e fingiram diferentes pedras, madeiras e tecidos. Essas ornamentações pictóricas enriqueceram os ambientes interiores dos templos, palácios e palacetes residenciais.

Tanto as pinturas de cavalete como as parietais - exemplificadas nesse artigo revelaram as tendências estéticas das épocas e dos contextos distintos nos quais foram produzidas, que se sucederam no tempo: as ideologias religiosas e políticas dos mecenas que encomendaram as obras; os ideais plásticos de seus criadores. As decorações pictóricas dos ambientes interiores são bens agregados às construções arquitetônicas e registram os artifícios requintados usados em cada período, que propagavam o status econômico, cultural e social das classes dominantes.

\section{REFERÊNCIAS}

BARDI, Pietro Maria. História da arte brasileira. São Paulo: Melhoramentos, 1977.

BAZIN, Germain. Aleijadinho et la sculture baroque au Brèsil. Paris: Gallimard, 1963.

BECKETT, Wendy. História da Pintura. São Paulo: Ática, 1997.

BRADBURNE, James. Illusioni: le meraviglie del trompe 1'oeil. Florença: Fondazione Palazzo Strozzi, 2009. 
BRUSCHINI, Enrico. Obras maetras del Vaticano. Roma: Edizioni Musei Vaticani, 2004.

CARPICECI, Alberto. Pompeia: hoje e como era 2000 anos atrás. Pompeia: Il Turismo, 2015.

CHAGAS, Mário de Souza. Conhecendo o Museu da República. Rio de Janeiro: Ao Livro Técnico, 1998.

Grandes Pinturas/ Dorling Kindersley. São Paulo: Publifolha, 2013.

Grandes artistas. São Paulo: Abril, s/d.

JANSON, H. W. Historia del arte. Barcelona: Labor, 1972.

LEMOS, Carlos Alberto. Arquitetura brasileira. São Paulo: Melhoramentos, 1979.

MANGUEL, Alberto. Lendo imagens. São Paulo: Companhia das Letras, 2001.

MAINSTONE, Madeleine e Rowland. O barroco e o século XVII. São Paulo: Zahar/Círculo do Livro, s/d.

Mestres da Pintura. São Paulo: Abril Cultural, 1977.

MORA, Paolo e Laura \& PHILIPPOT, Paul. La conservacion de las pinturas murales. Colômbia: Universidad Externado de Colômbia e ICCRON, 2003.

Pompeia reconstruída. Pompeia: Archeolibri, 2016.

SANTOS, Carlos Alberto Ávila. Ecletismo na fronteira meridional do Brasil: 18701931. 2007. Tese (Doutorado em Arquitetura e Urbanismo: Área de Conservação e Restauro) Faculdade de Arquitetura e Urbanismo da Universidade Federal da Bahia.

Construtores e artífices italianos no ecletismo do sul do Rio Grande do Sul.

In: Ecletismo em Pelotas: 1870-1931. Pelotas: UFPel, 2014.

SANTINI, Loretta. Venecia: arte e historia. Roma: Plurigraf, 1998.

SHEARMAN, John. O maneirismo. São Paulo: Cultrix, 1978.

SCHWARCZ, Lilia Moritz. As barbas do imperador: D. Pedro II, um monarca nos trópicos. São Paulo: Companhia das Letras, 1998.

VASARI, Giorgio. Vidas dos artistas. São Paulo: Martins Fontes, 2011.

WÖLFLLIN, Heinrich. Conceitos fundamentais da História da Arte. São Paulo: Martins Fontes, 1989. 